\section{REGIONAL CLIMATE EFFECTS OF IRRIGATION AND URBANIZATION IN THE WESTERN UNITED STATES: A MODEL INTERCOMPARISON}

Prepared For:

California Energy Commission

Public Interest Energy Research Program

Prepared By:

Mark A. Snyder, ${ }^{1}$ Lara M. Kueppers, ${ }^{1}$ Lisa C. Sloan, ${ }^{1}$ Dan Cayan, ${ }^{2,3}$ Jiming Jin, ${ }^{4}$ Hideki Kanamaru, ${ }^{2}$ Masao Kanamitsu, ${ }^{2}$ Norman L. Miller, ${ }^{4}$ Mary Tyree, ${ }^{2}$ Hui Du, ${ }^{5}$ and Bryan Weare $^{5}$

${ }^{1}$ University of California, Santa Cruz, ${ }^{2}$ Scripps Institution of Oceanography, University of California, San Diego, ${ }^{3}$ U.S. Geological Survey, ${ }^{4}$ Lawrence Berkeley National Laboratory, ${ }^{5}$ University of California, Davis

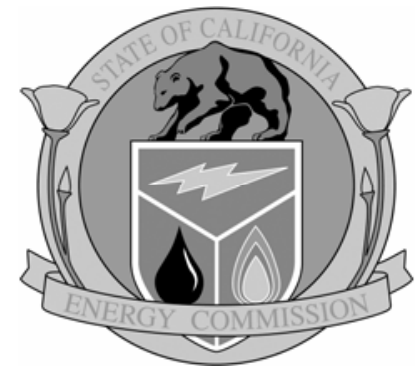

Arnold Schwarzenegger Governor

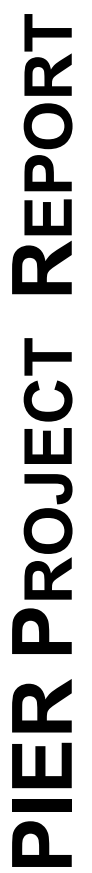

May 2006

CEC-500-2006-031 


\section{California Climate Change Center Report Series Number 2006-001}

\section{Prepared By:}

Mark A. Snyder, ${ }^{1}$ Lara M. Kueppers, ${ }^{1}$ Lisa C. Sloan, ${ }^{1}$ Dan Cayan, ${ }^{2,3}$ Jiming Jin, ${ }^{4}$ Hideki Kanamaru, ${ }^{2}$ Masao Kanamitsu, ${ }^{2}$ Norman L. Miller, ${ }^{4}$ Mary Tyree,${ }^{2}$ Hui Du, ${ }^{5}$ and Bryan Weare ${ }^{5}$

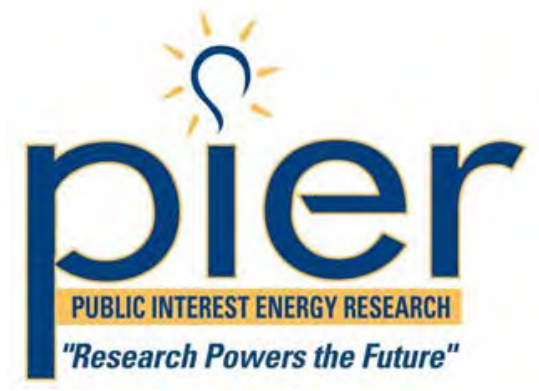

${ }^{1}$ University of California, Santa Cruz, ${ }^{2}$ Scripps Institution of Oceanography, University of California, San Diego, ${ }^{3}$ U.S. Geological Survey, ${ }^{4}$ Lawrence Berkeley National Laboratory, ${ }^{5}$ University of California, Davis

\section{Prepared For:}

California Energy Commission

Public Interest Energy Research (PIER) Program

Guido Franco,

Contract Manager

Kelly Birkinshaw, Program Area Manager Energy-Related Environmental Research

Martha Krebs, Ph.D.

Deputy Director

ENERGY RESEARCH AND DEVELOPMENT DIVISION

B. B. Blevins

Executive Director

\section{DISCLAIMER}

This report was prepared as the result of work sponsored by the California Energy Commission. It does not necessarily represent the views of the Energy Commission, its employees or the State of California. The Energy Commission, the State of California, its employees, contractors and subcontractors make no warrant, express or implied, and assume no legal liability for the information in this report; nor does any party represent that the uses of this information will not infringe upon privately owned rights. This report has not been approved or disapproved by the California Energy Commission nor has the California Energy Commission passed upon the accuracy or adequacy of the information in this report. 


\section{Acknowledgements}

This work was funded by the California Energy Commission Public Interest Energy Research (PIER) program, which supports the California Climate Change Center. The authors thank G. Franco for helpful conversations and comments on earlier versions of the manuscript. Thanks to S. Bryant (UCSC) for assistance with model runs, urban parameterizations, and data analysis, and T. O'Brien (UCSC) for assistance with figure preparation.

Please cite this report as follows:

Snyder, M. A., L. M. Kueppers, L. C. Sloan, D. Cayan, J. Jin, H. Kanamaru, M. Kanamitsu, N. L. Miller, M. Tyree, H. Du, and B. Weare. 2006. Regional Climate Effects of Irrigation and Urbanization in the Western United States: A Model Intercomparison. California Energy Commission, PIER Energy-Related Environmental Research. CEC-500-2006-031. 


\section{Preface}

The Public Interest Energy Research (PIER) Program supports public interest energy research and development that will help improve the quality of life in California by bringing environmentally safe, affordable, and reliable energy services and products to the marketplace.

The PIER Program, managed by the California Energy Commission (Energy Commission), annually awards up to $\$ 62$ million to conduct the most promising public interest energy research by partnering with Research, Development, and Demonstration (RD\&D) organizations, including individuals, businesses, utilities, and public or private research institutions.

PIER funding efforts are focused on the following RD\&D program areas:

- Buildings End-Use Energy Efficiency

- Energy-Related Environmental Research

- Energy Systems Integration

- Environmentally Preferred Advanced Generation

- Industrial/Agricultural/Water End-Use Energy Efficiency

- Renewable Energy Technologies

The California Climate Change Center (CCCC) is sponsored by the PIER program and coordinated by its Energy-Related Environmental Research area. The Center is managed by the California Energy Commission, Scripps Institution of Oceanography at the University of California at San Diego, and the University of California at Berkeley. The Scripps Institution of Oceanography conducts and administers research on climate change detection, analysis, and modeling; and the University of California at Berkeley conducts and administers research on economic analyses and policy issues. The Center also supports the Global Climate Change Grant Program, which offers competitive solicitations for climate research.

The California Climate Change Center Report Series details ongoing Center-sponsored research. As interim project results, these reports receive minimal editing, and the information contained in these reports may change; authors should be contacted for the most recent project results. By providing ready access to this timely research, the Center seeks to inform the public and expand dissemination of climate change information; thereby leveraging collaborative efforts and increasing the benefits of this research to California's citizens, environment, and economy.

The work described in this report was conducted under contract number 500-02-004, work authorization MR-025, by the Scripps Institution of Oceanography; the University of California, Santa Cruz, the University of California, Davis, and the Lawrence Berkeley National Laboratory (LBNL).

For more information on the PIER Program, please visit the Energy Commission's website www.energy.ca.gov/pier/ or contract the Energy Commission at (916) 654-5164. 


\section{Table of Contents}

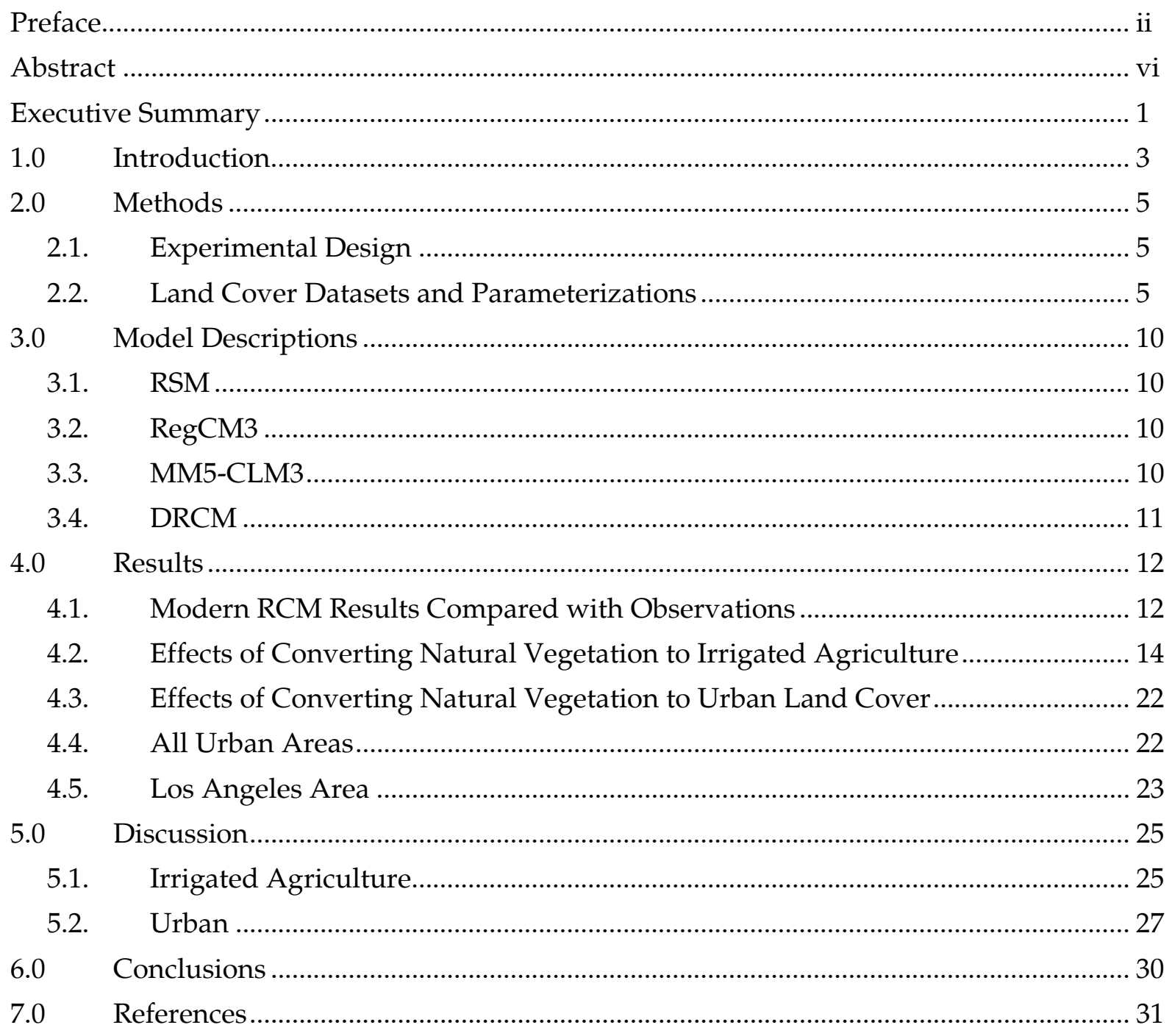




\section{List of Figures}

Figure 1. Potential natural (NAT) and modern (MOD) land cover types as represented by the four models. Types are aggregated into broader categories in this plot. A. NAT case RSM B. NAT case RegCM3 C. NAT case MM5-CLM3 D. NAT case DRCM E. MOD case RSM F. MOD case RegCM3 G. MOD case MM5-CLM3 H. MOD case DRCM.

Figure 2. January and August mean 2-meter temperature $\left({ }^{\circ} \mathrm{C}\right)$ from the four models, MOD case, compared to CRU mean temperature. A. January RSM B. January RegCM3 C. January MM5-CLM3 D. January DRCM E. January CRU F. August RSM G. August RegCM3 H. August MM5-CLM3 I. August DRCM J. August CRU..... 13

Figure 3. January and August surface vapor pressure (hPa) from the four models, MOD case, compared to CRU mean temperature. A. January RSM B. January RegCM3 C. January MM5-CLM3 D. January DRCM E. January CRU F. August RSM G. August RegCM3 H. August MM5-CLM3 I. August DRCM J. August CRU.

Figure 4. January and August soil moisture anomalies (MOD minus NAT) in mm. A. January RSM B. January RegCM3 C. January MM5-CLM3 D. January DRCM E. August RSM F. August RegCM3 G. August MM5-CLM3 H. August DRCM.

Figure 5. January and August latent heat flux anomalies (MOD minus NAT) in $\mathrm{W} / \mathrm{m}^{2}$. A. January RSM B. January RegCM3 C. January MM5-CLM3 D. January DRCM E. August RSM F. August RegCM3 G. August MM5-CLM3 H. August DRCM.

Figure 6. January and August mean 2-meter temperature anomalies (MOD minus NAT) $\left({ }^{\circ} \mathrm{C}\right)$. A. January RSM B. January RegCM3 C. January MM5-CLM3 D. January DRCM E. August RSM F. August RegCM3 G. August MM5-CLM3 H. August DRCM. 21

Figure 7. Monthly variation in climate differences between MOD and NAT averaged over irrigated agriculture in the Central Valley for the four models. A. Monthly soil moisture anomalies $(\mathrm{m} 3 / \mathrm{m} 3)$ B. Monthly maximum 2-meter temperature anomalies $\left({ }^{\circ} \mathrm{C}\right) \mathrm{C}$. Monthly latent heat flux anomalies $(\mathrm{W} / \mathrm{m} 2)$ D. Monthly minimum 2-meter temperature anomalies $\left({ }^{\circ} \mathrm{C}\right)$. 22

Figure 8. Los Angeles area NAT land cover with MOD urban areas outlined in black. August sensible heat flux $\left(\mathrm{W} / \mathrm{m}^{2}\right)$ and maximum temperature $\left({ }^{\circ} \mathrm{C}\right)$ anomalies (MOD minus NAT). A. RSM NAT vegetation and urban extent B. Same as A but for RegCM3 C. Same as A but for MM5-CLM3 D. Same as A but for DRCM E. RSM August sensible heat flux anomalies F. Same as E but for RegCM3 G. Same as E but for MM5-CLM3 H. Same as E but for DRCM I. RSM August 2-meter maximum temperature anomalies J. Same as I but for RegCM3 K. Same as I but for MM5-CLM3 L. Same as I but for DRCM. 28 


\section{List of Tables}

Table 1. Land cover types represented in the regional climate models ......................................... 7

Table 2. Properties of irrigated agriculture and urban land represented in the four RCMs...........8

Table 3. Change in near-surface climate variables between potential NAT vegetation and MOD vegetation cases (MOD-NAT) spatially averaged over all irrigated agricultural land ( $\mathrm{n}=133$ for RSM, n=65 for RegCM3, n=46 for MM5-CLM3, and n=64 grid cells for DRCM).

Table 4. Change in near surface climate variables between potential NAT vegetation and MOD vegetation cases (MOD-NAT) spatially averaged over irrigated agricultural land in California's Central Valley ( $\mathrm{n}=44$ for RSM, n=27 for RegCM3, n=21 for MM5-CLM3, and $\mathrm{n}=21$ grid cells for DRCM). Variables and units as in Table 3. 16

Table 5. Change in near surface climate variables between potential NAT vegetation and MOD vegetation cases spatially average over all urban land in the model domains. The number of grid cells for All urban, RegCM3: 11, RSM: 18, MM5-CLM3: 11 DRCM: 11. Variables and units as in Table 3

Table 6. Change in near surface climate variables between potential NAT vegetation and MOD vegetation cases spatially average over Los Angeles area urban land. The number of grid cells for LA urban, RegCM3: 5, RSM: 11, MM5-CLM3: 7. Variables and units as in Table 3. 


\begin{abstract}
In the western United States, more than 30,5000 square miles has been converted to irrigated agriculture and urban areas. This study compares the climate responses of four regional climate models (RCMs) to these past land-use changes. The RCMs used two contrasting land cover distributions: potential natural vegetation, and modern land cover that includes agriculture and urban areas. Three of the RCMs represented irrigation by supplementing soil moisture, producing large decreases in August mean $\left(-2.5^{\circ} \mathrm{F}\right.$ to $\left.-5.6^{\circ} \mathrm{F}\right)$ and maximum $\left(-5.2^{\circ} \mathrm{F}\right.$ to $\left.-10.1^{\circ} \mathrm{F}\right)$ 2-meter temperatures where natural vegetation was converted to irrigated agriculture. Conversion to irrigated agriculture also resulted in large increases in relative humidity $(9 \%-$ $36 \%$ absolute change). Only one of the RCMs produced increases in summer minimum temperature. Converting natural vegetation to urban land cover produced modest but discernable climate effects in all models, with the magnitude of the effects dependent upon the preexisting vegetation type. Overall, the RCM results indicate that land use change impacts are most pronounced during the summer months, when surface heating is strongest and differences in surface moisture between irrigated land and natural vegetation are largest. The irrigation effect on summer maximum temperatures is comparable in magnitude (but opposite in sign) to predicted future temperature change due to increasing greenhouse gas concentrations.
\end{abstract}

Keywords: DRCM, irrigated agriculture, land-use change, MM5-CLM3, model intercomparison, RegCM3, regional climate model (RCM), Regional Spectral Model (RSM), surface radiation budget, urban land cover. 


\section{Executive Summary}

\section{Introduction}

Modification of the land surface can lead to measurable changes in climate over a particular region. California and other parts of the western United States have experienced large-scale land surface modification, primarily through the conversion of natural vegetation to irrigated agriculture and urban areas.

\section{Purpose}

The purpose of this study was to understand what effect conversion of natural vegetation to irrigated agriculture and urban areas has had on the climate of California and other areas of the western United States. The study compared climate effects produced by four regional climate models to identify consistent results.

\section{Project Objectives}

1. Generate new land cover datasets for use in regional climate models

2. Create irrigated agriculture and urban land cover types within land surface models

3. Determine the impact of irrigated agriculture and urban land cover on the climate of California by comparing results from multiple regional climate models coupled with land surface models for two cases that differed only in the composition of the land cover

\section{Project Outcomes}

The conversion of natural vegetation to irrigated agriculture lead to reductions in maximum and mean surface air temperature through the introduction of additional moisture into the boundary layer. Surface energy balance was shifted, as evaporation of water from the irrigated areas required considerable energy. With conversion of natural vegetation to urban areas, the models produced small increases in maximum, mean, and minimum air temperature as a result of increases in sensible heat flux. The effects of land surface modification were more pronounced during the warm, dry summer months and less pronounced or absent during the cool, wet winter months.

\section{Conclusions}

Based on the model results, irrigated agriculture has likely influenced local climate through increased evapotranspiration-especially in the summer-leading to reduced maximum and mean surface air temperature. Urban land cover has likely had a small warming effect, but the role of urban areas in affecting climate requires more detailed investigation.

\section{Recommendations}

To better understand the full impact of land surface change on the climate of the California region, additional studies should be conducted with the following recommendations:

1. Improve representation of irrigated agriculture in the land surface models. The spatial and temporal heterogeneity of irrigation should be more fully explored using data on 
irrigation timing and extent, as there are variations in crop type that affect the amount of water applied.

2. Improve representation of urban areas in the land surface models. The character of urban areas varies across the state and needs to be captured in order to improve our understanding of the climate impacts of urbanization. The heterogeneity in urban areas comes from variations in building height, density, materials, and amount of vegetation, among other factors.

3. Conduct longer regional climate model runs to understand the role of natural climate variability in modulating the climate impact of irrigated agriculture and urban areas.

4. Conduct regional climate model runs that incorporate temporally varying greenhouse gas concentrations, in combination with land surface change, to better understand the interactions between these factors.

5. Incorporate the effects of aerosols into the regional climate models, to more fully capture the local and regional effects of human activity on atmospheric composition and climate in California

6. Employ a combination of observations and models to better understand moisture, heat, processes, and constituents in nocturnal and daytime boundary layer under varying seasonal and synoptic conditions.

7. Conduct detailed studies of regional climate model representation of the planetary boundary layer and other processes influencing surface temperature.

\section{Benefits to California}

Regional climate models are important tools for assessing the impact of land surface change in California. This project has improved our understanding of how past conversion of natural vegetation to irrigated agriculture and urban areas affect the climate of California. It also suggests how ongoing land use change may continue to influence regional climate. 


\subsection{Introduction}

Anthropogenic land-cover and land-use changes have dramatically altered the earth's surface; with agriculture, pasture, and urban land occupying more than 54 million square kilometers $\left(\mathrm{km}^{2}\right)$ (21 million square miles, $\mathrm{mi}^{2}$ ) (Leff et al., 2004), or $41 \%$ of Earth's ice-free land area. These large scale changes affect fresh water quality and quantity, carbon cycling, biodiversity, and climate (DeFries et al., 1999; Feddema et al., 2005; Kalnay and Cai, 2003; Pielke et al., 2002; Sala et al., 2000; Watson et al., 2000). The western United States (has seen rapid and extensive changes in land use over the past 150 years, and urban/suburban growth is projected to continue at a rate three times faster than the rest of the United States, for at least the next 50 years (Population Reference Bureau, 2004). Irrigated agricultural land in this region occupies $73,000 \mathrm{~km}^{2}\left(28,000 \mathrm{mi}^{2}\right)$, an area similar in size to the U.S. state of South Carolina (USDA, 2004), while urban and suburban land occupies more than $6,000 \mathrm{~km}^{2}\left(2,300 \mathrm{mi}^{2}\right)$.

Agricultural expansion and land management practices have both direct and indirect consequences for regional climates. Modern farming practices that use mineral fertilizers and extensive tilling can result in large losses of carbon from the soil to the atmosphere (Lal and Bruce, 1999). Conversely, practices such as conservation tillage, increased fallow times, and organic fertilizers can help rebuild soil carbon and sequester atmospheric carbon dioxide $\left(\mathrm{CO}_{2}\right)$ (Watson et al., 2000). The $\mathrm{CO}_{2}$ effects of land-use change are typically included in global climate model (GCM) simulations of anthropogenic climate change due to increased greenhouse gases (Houghton et al., 2001). More directly, conversion of natural ecosystems to farmland alters the surface roughness of vegetation, albedo, leaf conductance, and other properties that affect exchanges of water and energy between the land surface and atmosphere (Pielke et al., 2002). Heavy grazing can also decrease vegetative cover, reducing evapotranspiration and changing physical properties of the canopy, with climate implications. Widespread irrigation in semi-arid regions may also have a large climate impact. Recent analyses of historical observations in the San Joaquin Valley of California indicate that, in contrast to smaller changes at stations in the nearby Sierra Nevada mountains, the last several decades have exhibited decreases in daily maximum temperatures (Tmax) and marked increases in daily minimum temperatures (Tmin), especially in summer and fall (Christy and Norris, 2004; Christy et al. 2006). Christy et al. 2006 suggest that these changes have arisen in response to the development of extensive irrigation of this fertile valley. In one global modeling study, the effects of irrigation were to decrease surface temperature, increase relative humidity, and change the temperature profile of the troposphere, with geographic variations in the strength of these effects (Boucher et al., 2004).

Urban development also has consequences for local and regional climate. Urban climatic processes such as turbulent atmospheric fluxes, energy and water exchange, and the urban heat island have been extensively documented (Arnfeld, 2003). Replacing natural vegetation with roads and buildings decreases the surface albedo and alters the local surface energy balance, increasing sensible heat flux and decreasing latent heat flux. Intra-urban air temperature differences have been measured as high as $9^{\circ} \mathrm{C}\left(16^{\circ} \mathrm{F}\right)$ (Eliasson and Svensson, 2003) and $12^{\circ} \mathrm{C}$ $\left(22^{\circ} \mathrm{F}\right)$ (Oke, 1981). Previous modeling work at smaller spatial scales has suggested that even modest shifts in urban albedo can cause large changes in energy partitioning, local temperature, and even winds (Sailor, 1995). In the United States, impervious surface area covers over $100,000 \mathrm{~km}^{2}$ (Elvidge et al., 2004), with the potential to affect water percolation, runoff, evaporation, and radiation balance. In just the 48 contiguous states, land used for urban 
development increased 34\% between 1982 and 1997, increasing the total developed area from $3.9 \%$ to $5.2 \%$ (USDA Forest Service, 2001). Although they cover relatively large areas, and have measurable influence on local climates, urban land cover types and characteristics are often not included in climate modeling studies.

The domain considered in the present study is the western-most portion of the conterminous United States, with special focus upon the Central Valley of California and the Los Angeles metropolitan area. The western United States is primarily semi-arid, with summer drying in many sub-regions. This region has high topographic variability, including several mountain ranges that are not captured by GCM boundary conditions. The Central Valley of California is a 700 kilometers $(\mathrm{km})$ long, mostly closed valley that runs from northeast to southwest California, and is bounded by mountain ranges on all sides. It is not well ventilated, and therefore land surface properties may be especially important to local climate. Representation of realistic topography in such regions is extremely important for robust climate prediction (Giorgi et al., 1997; Snyder et al., 2002). Irrigation has been used to overcome rainfall deficiencies in many parts of the western United States, including the Central Valley, resulting in unnaturally high evapotranspiration fluxes from many agricultural areas, with implications for changes in the vertical temperature profiles and downwind precipitation. Large coastal cities have replaced a variety of natural vegetation types, with implications for temperature, humidity, and air quality. To quantify the effects of past urban and agricultural land-use change, and to incorporate the influence of the region's variable topography, this study used a regional climate modeling approach.

Regional climate models (RCMs) are used to investigate climate processes within limited domains, taking in large-scale climate information from GCMs or global observational datasets at their lateral boundaries. A number of RCMs have been previously validated and used for the western United States, including RegCM (Bell et al., 2004; Snyder et al., 2002; Snyder and Sloan, 2005), MM5 (Leung et al., 2004), RSM (Anderson et al., 2000; Chen et al., 1999), and MAS (Kim, 2001; Kim et al., 2002). The results from these models show improved representation of a number of climate variables relative to that produced by GCMs. This study used a RCM intercomparison approach to determine the modeled climate sensitivity to conversion of natural vegetation to modern vegetation that includes agricultural and urban land uses. By comparing results from several RCMs, it is possible to identify robust climate responses to land cover and land use change in this region. 


\subsection{Methods}

\subsection{Experimental Design}

This study used four RCMs (RSM, RegCM3, MM5-CLM3, and DRCM, described in detail in Section 3) to conduct similar climate model sensitivity experiments, using the same or similar initial and driving conditions imposed on two model runs which differed only in the characteristics of the land surface. The first run, using a modern vegetation distribution that included both irrigated and non-irrigated agriculture, as well as urban land, is termed $M O D$. The second run, using potential natural vegetation distribution designed for this experiment (see below), is termed NAT. The land surface data for the NAT runs do not include any agricultural or urban land cover types.

\subsection{Land Cover Datasets and Parameterizations}

Climate models represent the land surface with a limited suite of land cover and vegetation types. Associated parameters describe the height, albedo, and roughness of the canopy, and depending on the model, physiological properties such as leaf conductance and monthly variation in leaf area. Some models link soil albedo and texture to land cover type and some prescribe soils independently. The modern land cover for RSM, RegCM3, and MM5-CLM3 was derived from the Global Land Cover Characteristics (GLCC) database (version 2.0), which in turn is based on $1 \mathrm{~km}(0.6 \mathrm{mi})$ Advanced Very High Resolution Radiometer (AVHRR) data collected April 1992-March 1993 (Loveland et al., 2000). Because each RCM utilized a slightly different suite of natural and anthropogenic land cover types, this study created custom translations of the Olsen Global Ecosystems version of the GLCC data for the three models. The potential natural land cover was created at $1 \mathrm{~km}(0.6 \mathrm{mi})$ resolution based on the GLCC data by replacing anthropogenic types with their nearest-neighbor natural vegetation types. The resulting vegetation distributions were checked for consistency with another potential natural vegetation dataset (Ramankutty and Foley, 1999). Both modern and natural land cover datasets were then aggregated separately for each model to the coarser resolution grids for use in the experiment (Figure 1). In the DRCM regional climate model, an earlier version of the GLCC database (Loveland et al., 1995) was used to specify MOD vegetation. For the NAT case in DRCM, all urban and agricultural land in MOD was replaced with the "shrubland" vegetation type (Table 1). The resulting land cover distributions differed in the number and types of vegetation categories among the models. For example, RegCM3 represented much of the intermountain west as semi-desert and desert vegetation. None of the other three models have a "semi-desert" vegetation category, representing the same region as a mix of shrubland and desert vegetation (Table 1, Figure 1).

The four models varied in the manner by which soil moisture was altered to mimic irrigation in the irrigated cropland land cover type. Irrigated crop soil moisture was set to saturation at all time steps in RSM, while irrigated crop soil moisture was specified as field capacity at all time steps in RegCM3. Field capacity is the amount of water a column of soil can hold against the force of gravity, while saturation completely fills the available pore space with water. Therefore saturated soil is typically much wetter than soil at field capacity. In DRCM, an irrigation term was added to the surface soil moisture equation for all agricultural land, set to a uniform rate of $4.8225 \times 10^{-8}$ meters per second $\left(\mathrm{ms}^{-1}\right)$ of water when the top soil layer temperature is above $12^{\circ} \mathrm{C}$ 

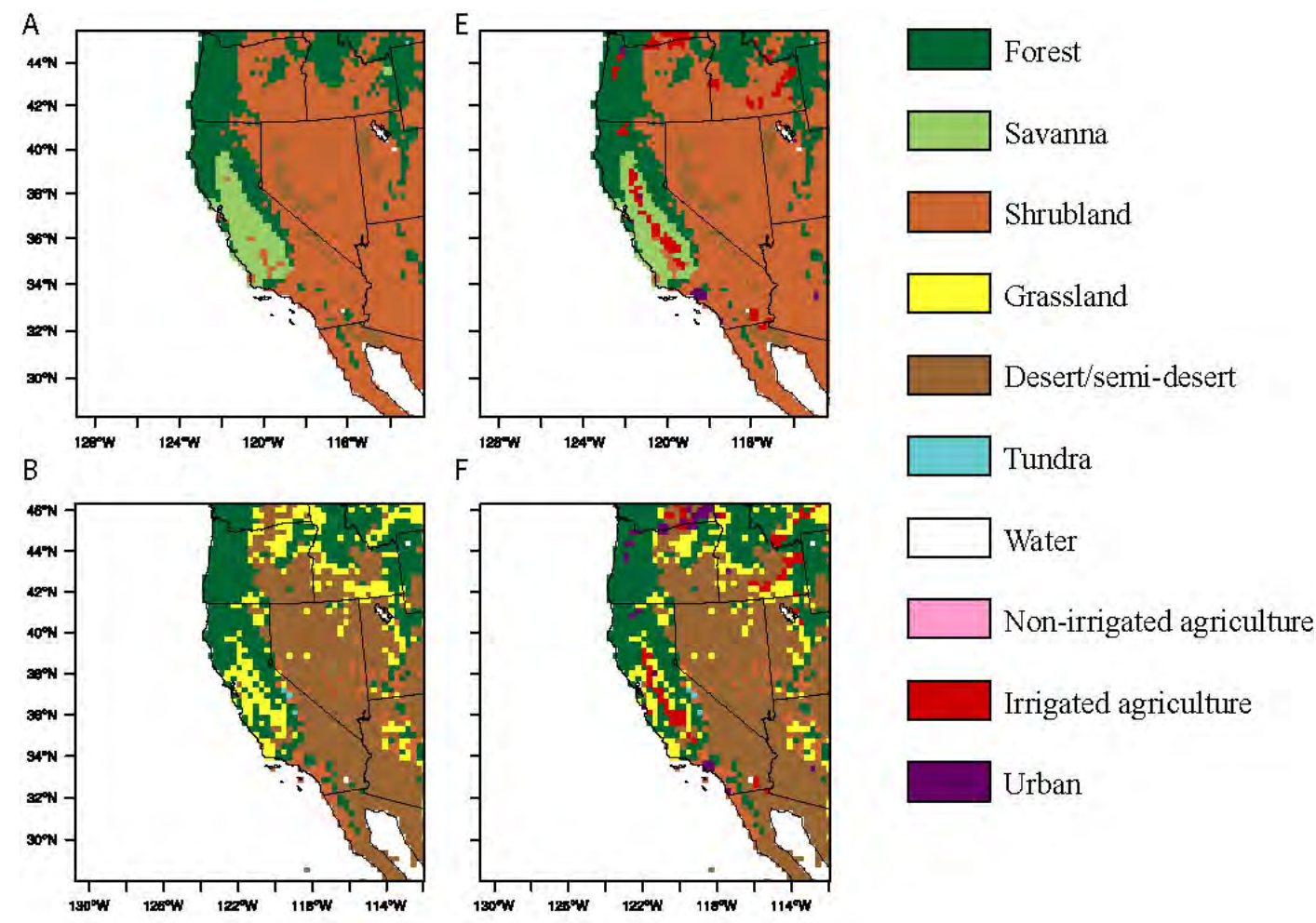

C

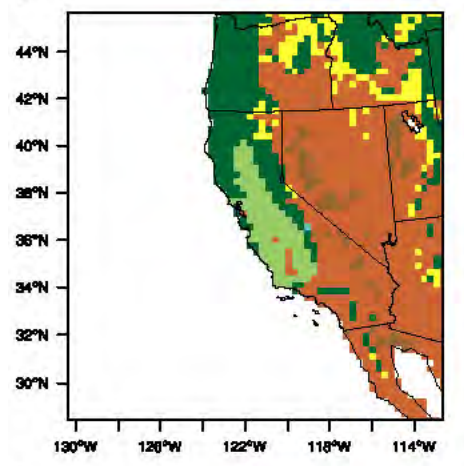

$G$

D
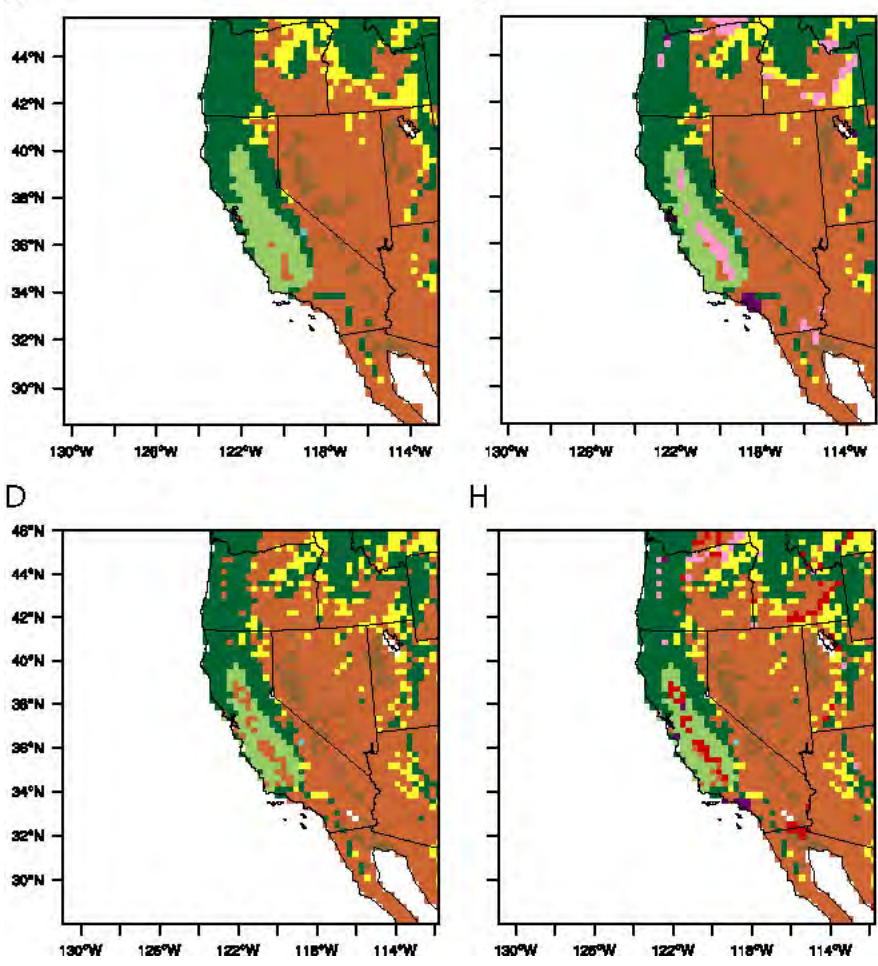

$\mathrm{H}$

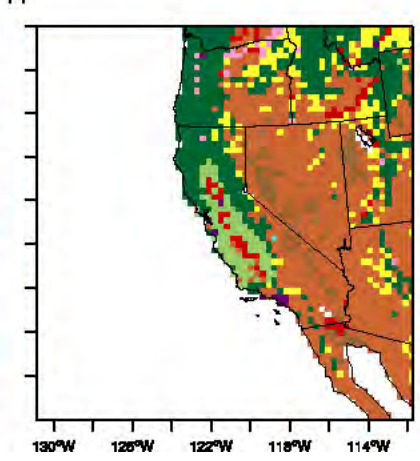

Figure 1. Potential natural (NAT) and modern (MOD) land cover types as represented by the four models. Types are aggregated into broader categories in this plot. A. NAT case RSM B. NAT case RegCM3 C. NAT case MM5-CLM3 D. NAT case DRCM E. MOD case RSM F. MOD case RegCM3 G. MOD case MM5-CLM3 H. MOD case DRCM. 
Table 1. Land cover types represented in the regional climate models

\begin{tabular}{|l|l|l|l|}
\hline Model & RSM & RegCM3 & MM5-CLM3 and DRCM \\
\hline $\begin{array}{l}\text { Urban and } \\
\text { crop }\end{array}$ & $\begin{array}{l}\text { Mixed farming/tall } \\
\text { grassland, irrigated } \\
\text { cropland, urban land }\end{array}$ & $\begin{array}{l}\text { Urban, suburban, } \\
\text { crop/mixed farming, } \\
\text { irrigated crop, } \\
\text { forest/field mosaic }\end{array}$ & $\begin{array}{l}\text { Urban/built-up land, dryland } \\
\text { cropland/pasture, irrigated } \\
\text { cropland/ pasture, mixed } \\
\text { dryland/irrigated cropland and } \\
\text { pasture, cropland/grassland } \\
\text { mosaic, cropland/woodland } \\
\text { mosaic }\end{array}$ \\
\hline Forest & $\begin{array}{l}\text { Deciduous forest, } \\
\text { tropical evergreen } \\
\text { broadleaved forest, } \\
\text { evergreen forest/needle } \\
\text { leaved forest, mixed } \\
\text { deciduous, and } \\
\text { evergreen forest }\end{array}$ & $\begin{array}{l}\text { Deciduous broadleaf } \\
\text { tree, deciduous } \\
\text { needleleaf tree, } \\
\text { evergreen broadleaf tree, } \\
\text { evergreen needleleaf } \\
\text { tree, mixed woodland }\end{array}$ & $\begin{array}{l}\text { Savanna, deciduous broadleaf } \\
\text { forest, deciduous needleleaf } \\
\text { forest, evergreen broadleaf } \\
\text { forest, evergreen needleleaf }\end{array}$ \\
forest, mixed forest
\end{tabular}


$\left(54^{\circ} \mathrm{F}\right)$, and zero when below this temperature. This rate, which is typical for California, corresponds to irrigating one meter over a 240-day season (Department of Water Resources, 1986). Unlike the other three models, MM5-CLM3 did not supplement soil moisture in areas with irrigated crops, but allowed it to vary as a function of rainfall, evapotranspiration, and drainage. All four models allow drainage of water from the upper soil layer to the lower layers. In addition to differences in the soil moisture regime in areas with irrigated crops, the models differed in prescribed geographically varying soil properties, canopy properties, and vegetation cover for the irrigated crop type (Table 2). Finally, RegCM3, MM5-CLM3, and DRCM represented monthly changes in crop properties, such as leaf area, whereas RSM did not.

Table 2. Properties of irrigated agriculture and urban land represented in the four RCMs

\begin{tabular}{|c|c|c|c|c|c|c|c|c|}
\hline & \multicolumn{4}{|c|}{ Irrigated Agriculture Parameters } & \multicolumn{4}{|c|}{ Urban Parameters } \\
\hline & RSM & RegCM3 & $\begin{array}{l}\text { MM5- } \\
\text { CLM3 }\end{array}$ & DRCM & RSM & RegCM3 & $\begin{array}{l}\text { MM5- } \\
\text { CLM3 }\end{array}$ & DRCM \\
\hline $\begin{array}{l}\text { Maximum } \\
\text { vegetation } \\
\text { cover }(\%) \\
\end{array}$ & 90 & 80 & 85 & 80 & 95 & 5 & $\mathrm{~N} / \mathrm{A}(0)$ & 10 \\
\hline $\begin{array}{l}\text { Roughness } \\
\text { length }(\mathrm{m})\end{array}$ & 0.06 & 0.06 & 0.06 & 0.07 & 0.2287 & 1.5 & 0.01 & 0.5 \\
\hline $\begin{array}{l}\text { Displacement } \\
\text { height }(\mathrm{m})\end{array}$ & $\mathrm{N} / \mathrm{A}$ & 0.0 & 0.34 & $\mathrm{~N} / \mathrm{A}$ & $\mathrm{N} / \mathrm{A}$ & 6.0 & $\mathrm{~N} / \mathrm{A}$ & $\mathrm{N} / \mathrm{A}$ \\
\hline $\begin{array}{l}\text { Minimum } \\
\text { stomatal } \\
\text { resistance } \\
(\mathrm{s} / \mathrm{m})\end{array}$ & 40 & 45 & $\begin{array}{l}\mathrm{N} / \mathrm{A} \\
\max \\
\text { resist: } \\
2 . \mathrm{e} 4 \\
(\mathrm{~s} / \mathrm{m})\end{array}$ & 36 & 999 & 120 & $\mathrm{~N} / \mathrm{A}$ & 999 \\
\hline $\begin{array}{l}\text { Maximum } \\
\text { leaf area } \\
\text { index } \\
\end{array}$ & $\mathrm{N} / \mathrm{A}$ & 6 & 6 & 4 & $\mathrm{~N} / \mathrm{A}$ & 1 & $\mathrm{~N} / \mathrm{A}$ & 4 \\
\hline $\begin{array}{l}\text { Top soil layer } \\
\text { depth }(\mathrm{cm})\end{array}$ & 10 & 10 & 1.75 & 7 & 10 & 10 & 1.75 & 7 \\
\hline $\begin{array}{l}\text { Total soil } \\
\text { depth }(\mathrm{m})\end{array}$ & 2 & 3 & 3.4 & 2.55 & 2 & 3 & 3.4 & 2.55 \\
\hline $\begin{array}{l}\text { Soil texture } \\
\text { type (one of } \\
\text { USDA types } \\
\text { or \% sand/ } \\
\text { silt/clay) }\end{array}$ & $\begin{array}{l}\text { Sandy } \\
\text { loam } \\
(58 / 32 / \\
10 \% \text {; sand/ } \\
\text { silt/clay) }\end{array}$ & 6 & $\begin{array}{l}\text { sandy- } \\
\text { clay- } \\
\text { loam }\end{array}$ & $\begin{array}{l}\text { Multiple } \\
\text { (USDA) }\end{array}$ & $\begin{array}{l}\text { Loamy } \\
\text { sand } \\
(82 / 12 / \\
6 \% \text {; sand/ } \\
\text { silt/clay)* }\end{array}$ & $\begin{array}{l}12 \\
\text { (USDA) }\end{array}$ & 1 (USGS) & $\begin{array}{l}\text { Multiple } \\
\text { (USDA) }\end{array}$ \\
\hline $\begin{array}{l}\text { Vegetation } \\
\text { Albedo }\end{array}$ & $\begin{array}{l}\text { VIS: } 0.10 \text {; } \\
\text { NIR: } 0.30\end{array}$ & $\begin{array}{l}\text { VIS: } 0.08 \text {; } \\
\text { NIR: } 0.28\end{array}$ & $\begin{array}{l}\text { VIS: } 0.11 \\
\text { NIR: } 0.58\end{array}$ & $\begin{array}{l}\text { Total } \\
\text { albedo } \\
0.15-0.19\end{array}$ & $\begin{array}{l}\text { VIS: } 0.09 ; \\
\text { NIR: } 0.29\end{array}$ & $\begin{array}{l}\text { VIS: } \\
0.02 ; \\
\text { NIR:0.15 }\end{array}$ & $\mathrm{N} / \mathrm{A}$ & $\begin{array}{l}\text { Total } \\
\text { albedo } \\
0.15\end{array}$ \\
\hline
\end{tabular}

* Soil types are parameterized separately from vegetation types; values given are the dominant values for the urban and agricultural grid cells in the MOD case. 
The urban land cover type is also parameterized differently among the models (Table 2). Relative to the natural vegetation it replaced (typically shrubland), urban land in RSM was given a lower albedo, a mid-range roughness length, and a high vegetation cover with a very large stomatal resistance to mimic the urban surface (Table 2). For this study, RegCM3's land surface model was modified to include new urban and suburban land cover types, adding them to the 22 pre-existing land cover types (Table 1). Based on published values, the urban land cover type was defined to have clayey soil, low albedo, low vegetation cover, and relatively tall displacement height (Grimmond and Oke, 1999; Pauleit and Duhne, 2000; Sailor, 1995). MM5CLM3 represented urban areas as bare soil, and did not modify any other parameters in urban areas in the MOD case relative to the NAT case. In DRCM a unique land surface type represents urban areas, and the soil moisture was fixed at a low level (0.05 kilograms per kilogram, or $\mathrm{kg} / \mathrm{kg}$ ). The models did not include the effects of anthropogenic heat release due to combustion (Sailor, 1995). 


\subsection{Model Descriptions}

\subsection{RSM}

The version of the Regional Spectral Model (RSM) (Juang and Kanamitsu, 1994) used for this study was originally developed at the National Centers for Environmental Prediction (NCEP), and subsequently updated at the Experimental Climate Prediction Center (ECPC) of the Scripps Institution of Oceanography (SIO) (Kanamitsu et al., 2005). The RSM applies sine and cosine series to the deviation of the full forecast field from the global base field (perturbations), and is capable of very accurate and efficient spectral calculations (Juang and Kanamitsu, 1994). A "scale selective bias correction scheme" (Kanamaru and Kanamitsu, 2005) was used to reduce error relative to the reanalysis boundary conditions in the large-scale $(>1000 \mathrm{~km})$ fields within in the regional domain. RSM uses the relaxed Arakawa-Schubert convection scheme (Moorthi and Suarez, 1992) and radiation package of Chou (Chou and Lee, 1996; Chou and Suarez, 1994). The land surface model used in RSM is the Oregon State University Land Scheme (OSU2, Pan and Mahrt, 1987). It includes 12 United States Geological Survey (USGS) vegetation types; two more types (irrigated cropland and urban land) were added for this study (Table 1). OSU2 has two soil layers, with a top layer of 10 centimeters $(\mathrm{cm})(3.9$ inches, in) and total soil depth of 2 meters (m) (6.6 feet, $\mathrm{ft})$. Soil type was not changed between the two cases.

\subsection{RegCM3}

The International Center for Theoretical Physics (ICTP) Regional Climate Model, RegCM3 (Pal et al., submitted), is a third-generation regional-scale climate model derived from the National Center for Atmospheric Research-Pennsylvania State (NCAR-PSU) MM5 mesoscale model. RegCM3 includes the same dynamical core as MM5. Improvements to RegCM3 over previous versions include a new large-scale cloud and precipitation scheme, SUBEX (Pal et al., 2000), a new ocean flux parameterization (Zeng et al., 1998), and the availability of a new cumulus convection scheme (Betts, 1986). RegCM3 includes the Biosphere-Atmosphere Transfer Scheme (BATS1E) (Dickinson et al., 1993) for surface process representation and the CCM3 radiative transfer package (Kiehl et al., 1996). RegCM3 documentation and source code are available at www.ictp.trieste.it/RegCNET/model.html.

The model was configured for these experiments with the Grell cumulus scheme (Grell, 1993) utilizing the Fritsch and Chappell closure scheme (Fritsch and Chappell, 1980) and also the Holtslag boundary layer scheme (Holtslag and Boville, 1993; Holtslag et al., 1990). BATS1E has three soil layers, with a top soil layer of $10 \mathrm{~cm}$ (3.9 in), rooting depth varying between 1 and $2 \mathrm{~m}$ (3.3 and $6.6 \mathrm{ft}$ ), depending on land cover type, and total soil depth of $3 \mathrm{~m}(9.8 \mathrm{ft})$.

\subsection{MM5-CLM3}

The non-hydrostatic version of MM5 coupled with CLM3 (Jin and Miller, 2006) was used in this study. The Grell convection scheme was adopted to parameterize cumulus clouds (Grell, 1993), and the Medium Range Forecast (MRF) planetary boundary layer (PBL) scheme was applied to solve boundary layer processes (Hong and Pan, 1996). The radiation scheme was taken from Community Climate Model version 2 (CCM2) developed by NCAR. At each gridcell, CLM3 represents snow processes with five layers, soil processes with ten layers, and vegetation processes are represented as one layer. (Oleson et al., 2004). The top soil layer is $1.75 \mathrm{~cm}(0.69 \mathrm{in})$ thick, and the total soil depth is $3.4 \mathrm{~m}(11.2 \mathrm{ft})$. Mass and heat transfer are described using a 
simple crop scheme. In this coupled version using CLM3, a sophisticated surface albedo scheme was adopted to improve the surface energy balance simulations (Jin and Miller, 2006; Oleson et al., 2004). Introduction of a maximum of 8 sub-cells within each CLM3 cell is shown to improve the accuracy of the land surface characterization and the land surface-atmosphere water and energy flux exchanges. The cropland in CLM3 is specified according to leaf area index, roughness length, and vegetation fraction. Irrigated cropland and urban land schemes are still under development in CLM3.

\subsection{DRCM}

The Davis Regional Climate Model (DRCM) is a regional-scale climate model derived from the NCAR-PSU MM5V3.6 mesoscale model. The configuration used in this study includes the fivephase (cloud drops, rain, ice, snow, and graupel) Goddard precipitation scheme (Lin et al., 1983; Tao et al., 1989), the relaxed Arakawa-Schubert convection (Grell, 1993), the Mellor-Yamada 2.5-level planetary boundary layer (Janjic, 1990; Janjic, 1994), the Rapid Radiation Transfer Model (Mlawer et al., 1997), and a slightly modified version of the fully interactive Noah land surface model vegetative surface/hydrology scheme (Chen and Dudhia, 2001). The physical attributes of the vegetation for summer and winter are specified for 24 land surface types; soil properties are defined for 19 soil types. Noah has 4 soil layers, with a top layer of $7 \mathrm{~cm}(2.8 \mathrm{in})$ and total soil depth of $2.55 \mathrm{~m}(8.37 \mathrm{ft})$.

All four RCMs used a common domain centered on $37.5 \mathrm{~N} / 121.5 \mathrm{~W}$, spanning approximately $29^{\circ} \mathrm{N}$ to $45.5^{\circ} \mathrm{N}$ and $110^{\circ} \mathrm{W}$ to $132^{\circ} \mathrm{W}\left(100^{\circ} \mathrm{W}\right.$ to $140^{\circ} \mathrm{W}$ for DRCM). RSM was run at a $25 \mathrm{~km}$ (16 mi) horizontal resolution, and RegCM3, MM5-CLM3, and DRCM at $30 \mathrm{~km}$ (19 mi). RSM, RegCM3, and MM5-CLM3 used the NCEP/DOE Reanalysis II (Kanamitsu et al., 2002) as lateral boundary condition data, while DRCM used the ERA-40 (Gibson et al., 1997). All models were run from 1 October 1995 through 30 September 1996, with RegCM3 runs starting in October 1993, MM5-CLM3 runs starting in September 1995, and DRCM runs starting in August 1995 to allow time for model spin-up. All models used prescribed sea surface temperatures (SSTs) over the ocean from the NOAA OISST (National Oceanic and Atmospheric Administration optimally interpolated sea surface temperature) dataset (Reynolds et al., 2002) for the appropriate time period. Finally, the models used similar $\mathrm{CO}_{2}$ concentrations, held constant for the two experimental runs (348 ppm in RSM, 355 ppm in RegCM3 and MM5-CLM3, and 330ppm in DRCM).

As a model validation step, this study compared monthly average output from the MOD runs by the four RCMs to gridded observations from the University of East Anglia Climate Research Unit (CRU) high-resolution, time-series dataset TS2.1 (Mitchell and Jones, 2005). It compared the simulated $2 \mathrm{~m}(6.6 \mathrm{ft})$ mean, maximum, and minimum temperatures, and temperature range to the same CRU values. It also compared simulated and CRU precipitation and surface vapor pressure. This report focuses on January and August 1996, as they represent the wet/cool- and dry/warm-seasons, respectively, in this region. 


\subsection{Results}

\subsection{Modern RCM Results Compared with Observations}

January $2 \mathrm{~m}(6.6 \mathrm{ft})$ mean temperatures (Tmean) were represented reasonably accurately by all of the models, with warmer temperatures in the south, along the coast, and penetrating into California's Central Valley, and with colder temperatures inland and at high elevations (Figure 2). Tmean values produced by RSM were slightly warmer than observations in southeastern Oregon, while Tmean values produced by MM5-CLM3 and DRCM were slightly cooler than observations in western Nevada. DRCM also produced Tmean values cooler than observations in southern California (Figure 2). In August, Tmean was also consistent with observations, with DRCM underestimating temperatures in the Central Valley, southern California, and western Nevada (Figure 2). RSM and RegCM3 also underestimated temperature in the core of the Central Valley. All models slightly overestimated August Tmean along the southern California coast.

All of the models captured observed January maximum $2 \mathrm{~m}(6.6 \mathrm{ft})$ temperature (Tmax) patterns, however most of the models had modest to substantial cold biases. DRCM produced temperatures colder than observations throughout the modeled domain, while MM5-CLM3 produced maximums that were too cool along the California coast, in the Central Valley, and in Nevada. RegCM3 produced maximums that were too cool in Nevada and northeastern California. In August, the models varied in their ability to represent the magnitude and pattern of Tmax. RSM and MM5-CLM3 underestimated Tmax in much of Nevada, while RSM and RegCM3 underestimated Tmax in parts of the Central Valley, where they supplemented soil moisture for irrigated cropland. DRCM underestimated August Tmax throughout the modeled domain.

All of the models overestimated observed January minimum temperatures (Tmin) along the central California coast and in the Central Valley. RSM, RegCM3, and DRCM output also overestimated Tmin in Nevada and eastern Oregon. In August, all of the models produced minimum temperatures more closely matched to observations. MM5-CLM3 and DRCM produced minimums that were too cool in the southern Sierra Nevada range, while RSM produced minimums that were slightly warm in this area. RSM, RegCM3, and MM5-CLM3 all produced overly warm Tmin values at the northern end of the Central Valley.

All four models underestimated the diurnal temperature range (DTR) in January throughout the model domain. The pattern of increasing DTR from northwest to southeast was weakly reproduced in RSM, RegCM3, and MM5-CLM3. The models, particularly RSM and DRCM, also underestimated DTR in August. None of the models reproduced the "bull's-eye" pattern centered over Nevada that exists in the August observational data. The consistent underestimation across models and seasons could be due to differences in how DTR are calculated between the models and data, or to actual dampened diurnal cycles in the models.

All models, except DRCM, overestimated January precipitation in the high precipitation areas of northern coastal California, the Oregon Cascade range, and the Sierra Nevada range when compared to CRU observations. These three models also overestimated January precipitation in northern Nevada. However, given the scarcity of weather stations in these remote areas, the 

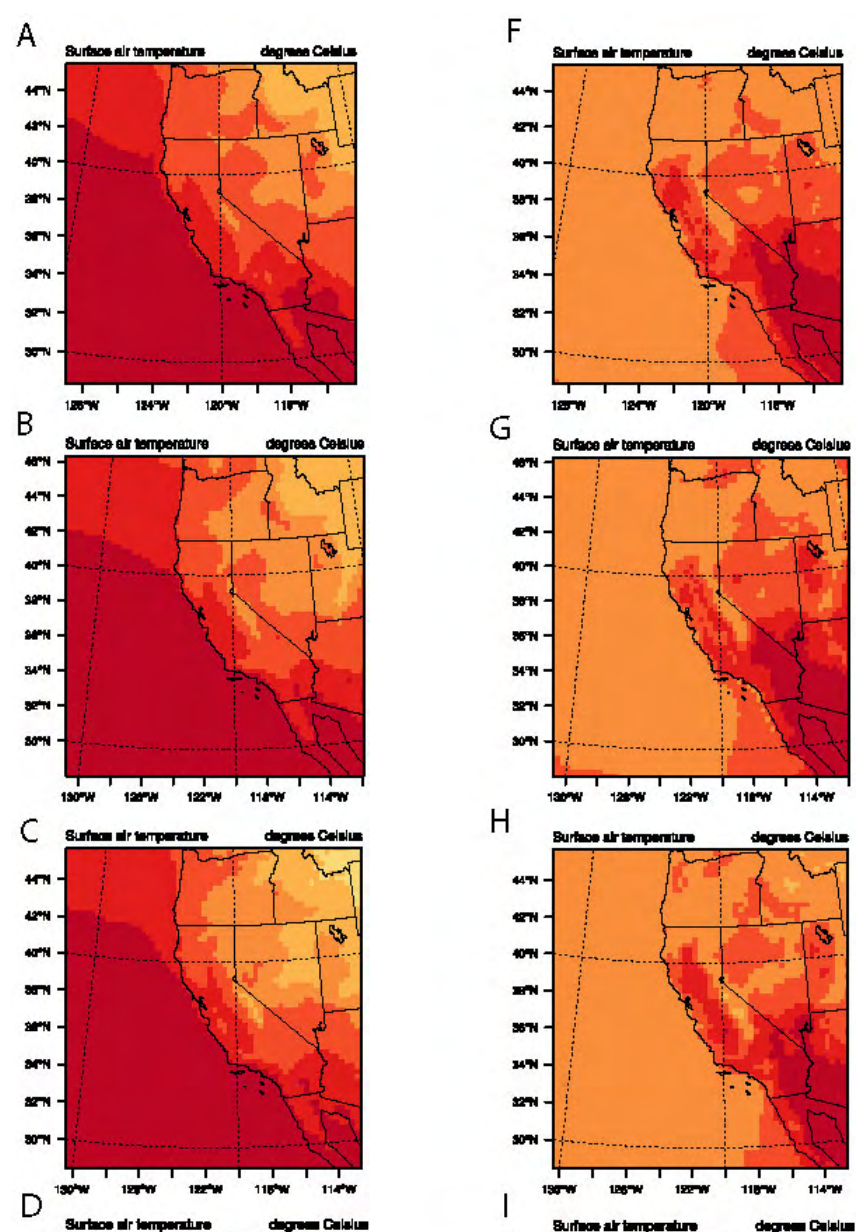

$\mathrm{H}$
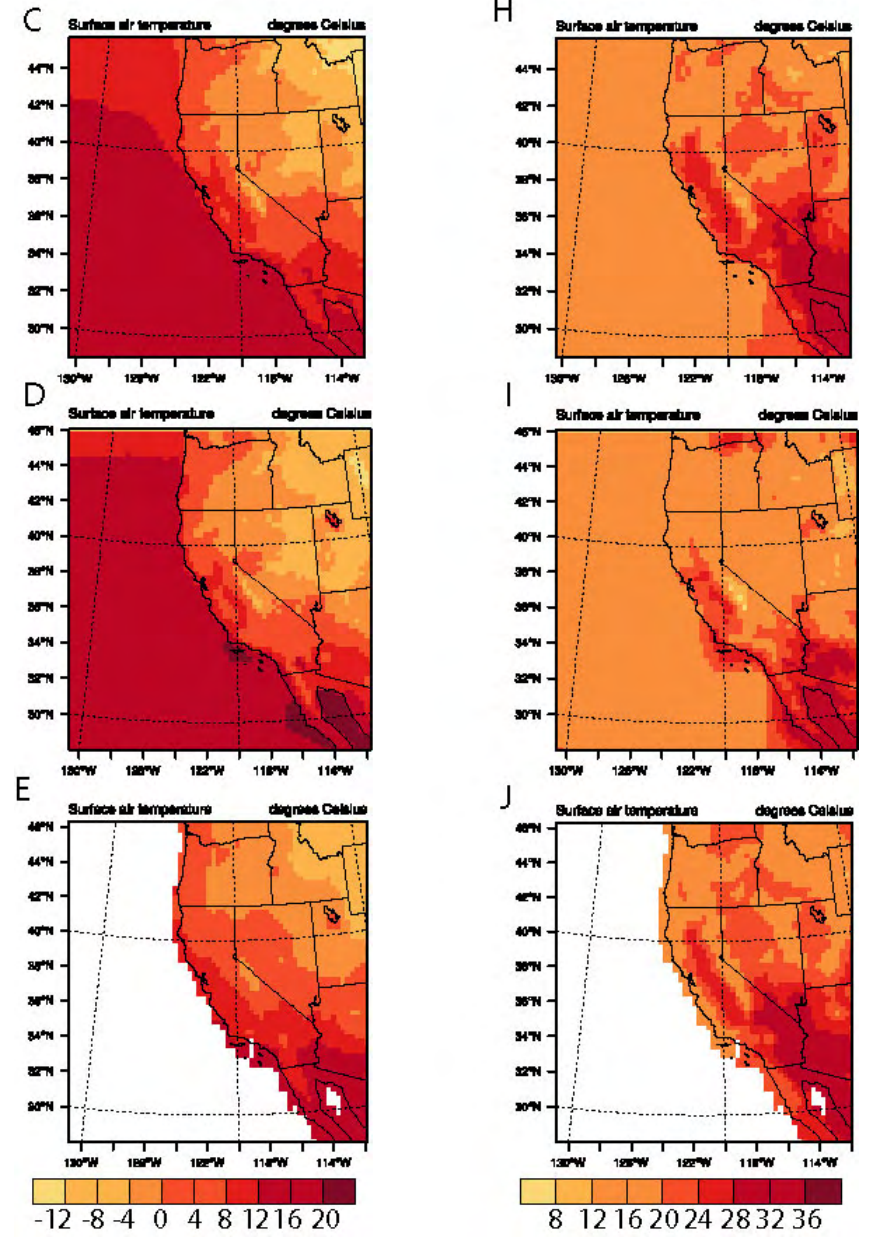

Figure 2. January and August mean 2-meter temperature $\left({ }^{\circ} \mathrm{C}\right)$ from the four models, MOD case, compared to CRU mean temperature. A. January RSM B. January RegCM3 C. January MM5-CLM3 D. January DRCM E. January CRU F. August RSM G. August

RegCM3 H. August MM5-CLM3 I. August DRCM J. August CRU. 
true discrepancy between models and interpolated data is poorly constrained. DRCM tended to underestimate January precipitation along the central and southern California coast. All of the models produced more spatial variability in August precipitation than is evident in the CRU observations. RegCM3 overestimated August rainfall throughout much of the domain, especially in Oregon and southern Idaho.

Surface vapor pressure was generally represented well by all models in January (Figure 3). DRCM underestimated vapor pressure in much of California and western Arizona, while RegCM3 underestimated vapor pressure in southeastern California. RSM overestimated vapor pressure in the core of the Central Valley, likely a result of prescribing saturated soil under irrigated agricultural land (see discussion). In August, RSM overestimated vapor pressure in areas specified as irrigated agriculture, particularly in California's Central Valley, Imperial Valley, and southeastern Idaho (Figure 3). RSM, RegCM3, and MM5-CLM3 overestimated vapor pressure in eastern Oregon and parts of Idaho, and RSM and RegCM3 underestimated vapor pressure in the California-Arizona-Mexico border region. DRCM underestimated vapor pressure in the southern half of the modeled domain (Figure 3).

\subsection{Effects of Converting Natural Vegetation to Irrigated Agriculture}

The climate effects of converting potential natural vegetation to irrigated agriculture were quantified as the difference between the two cases, MOD - NAT, for each model and all variables. As with the comparison to observations, the results here focus on the months of January and August. In addition, this study looked at changes in climate variables spatially averaged over all areas that were irrigated, and averaged over the subset of irrigated grid cells located in the Central Valley of California. This long, intensively farmed valley experiences higher summer temperatures (Figure 2) and lower summer precipitation than most other agricultural areas in the modeled domain.

In January, RegCM3, MM5-CLM3, and DRCM had few differences in soil moisture between the MOD and NAT cases (Table 3, Figure 4). Increased soil moisture from irrigation was only weakly evident in southern California's Imperial Valley in RegCM3 output. Conversely, RSM produced a large difference in soil moisture $(+25 \mathrm{~mm})$ between the cases in all irrigated areas, a result of specifying soil moisture at saturation throughout the year. In August, RSM, RegCM3, and DRCM produced increased soil moisture where irrigation occurred in MOD, by 9-47 mm $(0.35-1.8$ in) $(180 \%-550 \%)$ averaged over all irrigated areas, and by $10-48 \mathrm{~mm}$ (0.39-1.9 in) $(220 \%-640 \%)$ in the Central Valley (Tables 3, 4). MM5-CLM3 produced no difference in August soil moisture between cases, reflecting the fact that soil moisture was not supplemented in irrigated regions. 

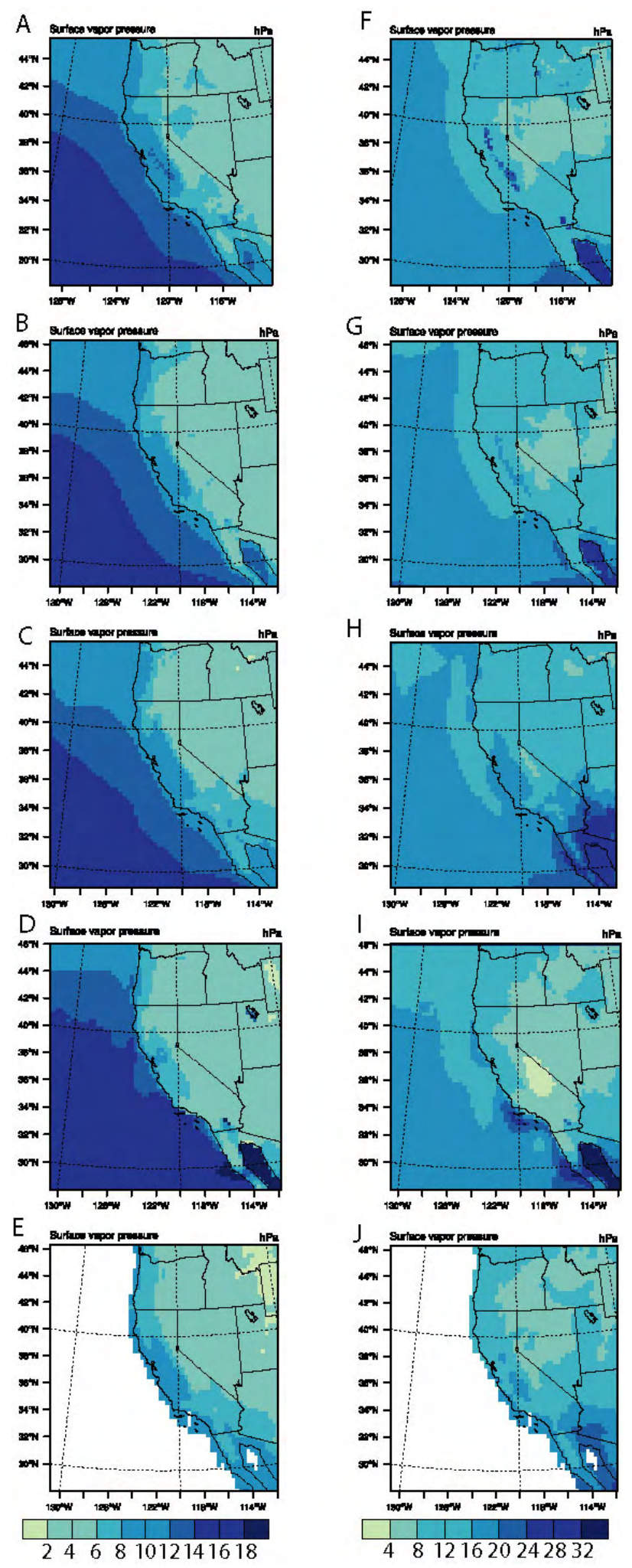

Figure 3. January and August surface vapor pressure $(\mathrm{hPa})$ from the four models, MOD case, compared to CRU mean temperature. A. January RSM B. January RegCM3 C. January MM5-CLM3 D. January DRCM E. January CRU F. August RSM G. August RegCM3 H. August MM5-CLM3 I. August DRCM J. August CRU. 
Table 3. Change in near-surface climate variables between potential NAT vegetation and MOD vegetation cases (MOD-NAT) spatially averaged over all irrigated agricultural land ( $n=133$ for RSM, n=65 for RegCM3, n=46 for MM5-CLM3, and $n=64$ grid cells for DRCM).

\begin{tabular}{|c|c|c|c|c|c|c|c|c|}
\hline & Jan & & & & Aug & & & \\
\hline Variable & RSM & RegCM3 & $\begin{array}{l}\text { MM5- } \\
\text { CLM3 }\end{array}$ & DRCM & RSM & RegCM3 & $\begin{array}{l}\text { MM5- } \\
\text { CLM3 }\end{array}$ & DRCM \\
\hline Tmean & 0.23 & 0.06 & -0.09 & -0.11 & -1.48 & -3.09 & -0.92 & -1.44 \\
\hline Tmax & -0.28 & -0.15 & -0.1 & -0.27 & -3.12 & -6.14 & -0.41 & -2.9 \\
\hline Tmin & 0.76 & 0.22 & 0 & 0.05 & 1.99 & -0.84 & -1.35 & 0.1 \\
\hline DTR & -1.04 & -0.37 & -0.1 & -0.32 & -5.11 & -5.3 & 0.94 & -3 \\
\hline LHFS & 0.7 & 1.74 & -4.05 & 5.48 & 109.99 & 133.5 & -0.6 & 99.98 \\
\hline SHFS & 0.09 & -1.26 & 4.19 & -3.09 & -102.27 & -98.72 & -20.05 & -76.2 \\
\hline SMT & 25.15 & 2.36 & 0.17 & 2.56 & 46.61 & 21.5 & 0.25 & 8.94 \\
\hline RHS & 1.6 & 0.32 & -2.44 & 1.89 & 35.81 & 22.96 & 1.62 & 8.78 \\
\hline
\end{tabular}

Tmean, mean 2-meter temperature (Celsius); Tmax, maximum 2-meter temperature (Celsius); Tmin, minimum 2-meter temperature (Celsius); DTR, 2-meter diurnal temperature range (Celsius); LHFS, latent heat flux at land surface $\left(\mathrm{W} / \mathrm{m}^{2}\right)$; SHFS, sensible heat flux at land surface $\left(\mathrm{W} / \mathrm{m}^{2}\right)$; SMT, top soil layer soil moisture (mm); RHS, $2 \mathrm{~m}$ relative humidity $(\%)$.

Table 4. Change in near surface climate variables between potential NAT vegetation and MOD vegetation cases (MOD-NAT) spatially averaged over irrigated agricultural land in California's Central Valley ( $n=44$ for RSM, $n=27$ for RegCM3, $n=21$ for MM5-CLM3, and $\mathrm{n}=\mathbf{2 1}$ grid cells for DRCM). Variables and units as in Table 3.

\begin{tabular}{|c|c|c|c|c|c|c|c|c|}
\hline & \multicolumn{4}{|l|}{ Jan } & \multicolumn{4}{|l|}{ Aug } \\
\hline Variable & RSM & RegCM3 & $\begin{array}{l}\text { MM5- } \\
\text { CLM3 }\end{array}$ & DRCM & RSM & RegCM3 & $\begin{array}{l}\text { MM5- } \\
\text { CLM3 }\end{array}$ & DRCM \\
\hline Tmean & 0.47 & 0.15 & 0.42 & -0.15 & -2.91 & -3.94 & -0.54 & -2.29 \\
\hline Tmax & -0.54 & -0.05 & 0.3 & -0.24 & -6.06 & -8.18 & -0.31 & -4.69 \\
\hline Tmin & 1.14 & 0.27 & 0.62 & -0.09 & 2.29 & -0.83 & -0.71 & 0.04 \\
\hline DTR & -1.68 & -0.32 & -0.32 & -0.15 & -8.35 & -7.35 & 0.4 & -4.72 \\
\hline LHFS & -4.72 & -0.09 & -2.28 & 4.67 & 133.34 & 142.32 & -0.36 & 137.9 \\
\hline SHFS & 2.41 & 0.64 & 5.82 & -2.43 & -123.55 & -107.23 & -12.53 & -104.9 \\
\hline SMT & 24.46 & 1.53 & 0.24 & 1.89 & 47.52 & 23.15 & 0.27 & 10.45 \\
\hline RHS & -0.44 & -0.51 & -3.26 & 2.24 & 44.79 & 27.07 & 1.68 & 13.48 \\
\hline
\end{tabular}



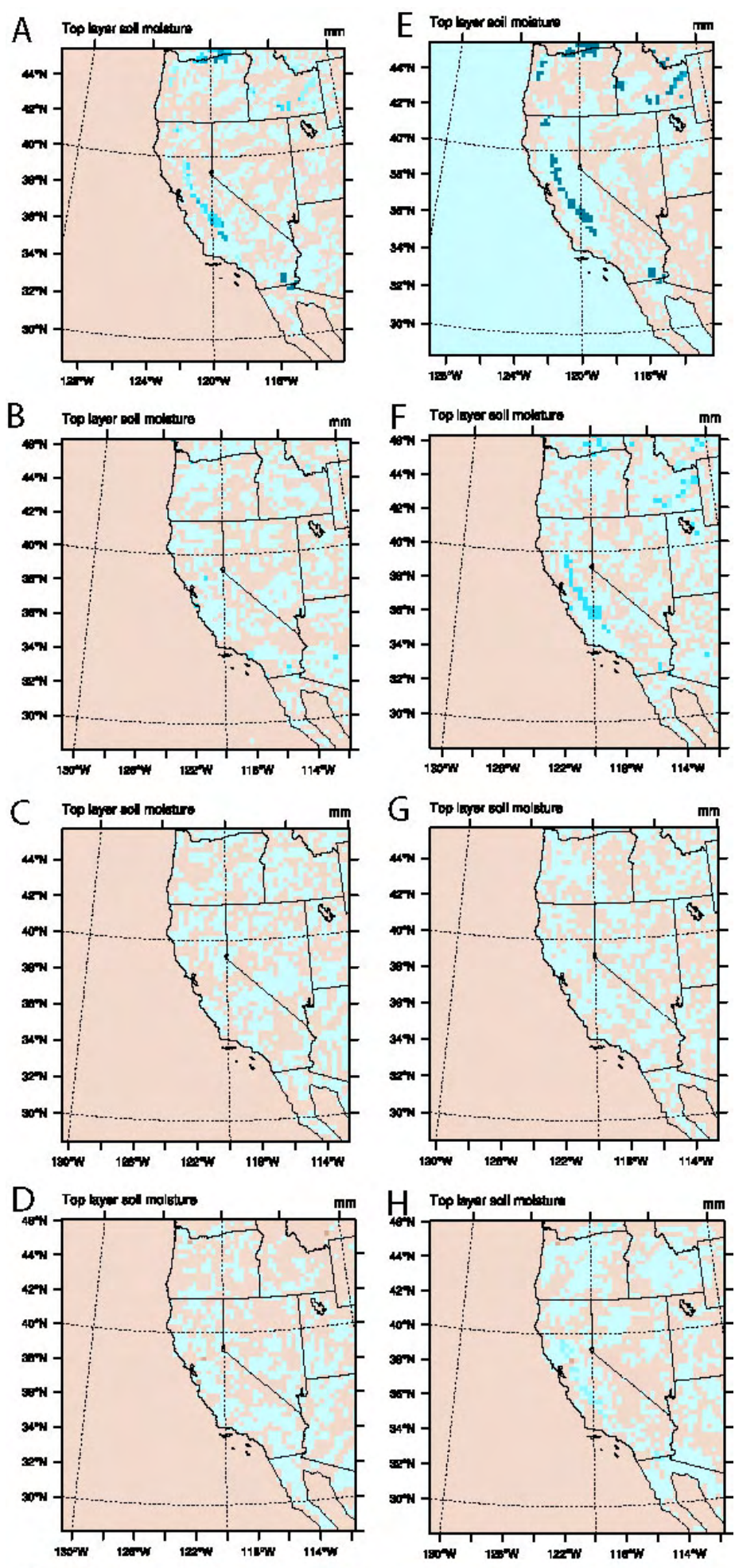

$\begin{array}{rlllllll}-40-30 & -20 & -10 & 0 & 10 & 20 & 30 & 40\end{array}$

Figure 4. January and August soil moisture anomalies (MOD minus NAT) in mm. A. January RSM B. January RegCM3 C. January MM5-CLM3 D. January DRCM E. August RSM F. August RegCM3 G. August MM5-CLM3 H. August DRCM. 
In January, both RSM and RegCM3 produced more than 40 watts per square meter $\left(\mathrm{W} / \mathrm{m}^{2}\right)$ greater latent heat flux over the Imperial Valley where irrigated agriculture replaced desert or grassland vegetation (Figure 5). DRCM produced more modest increases in latent heat flux in this area. RSM also produced decreases in January latent heat flux (by up to $30 \mathrm{~W} / \mathrm{m}^{2}$ ) where irrigated crop replaced forest or woodland vegetation in parts of California's Central Valley, Oregon, and Idaho. In August, RSM, RegCM3, and DRCM produced substantial increases in latent heat flux in all areas converted to irrigated agriculture from natural vegetation $\left(+100-133 \mathrm{~W} / \mathrm{m}^{2}\right)$ (Table 3). August latent heat fluxes in the NAT case averaged $25-35 \mathrm{~W} / \mathrm{m}^{2}$ in these models, meaning conversion from natural vegetation to irrigated agriculture yielded a fivefold increase in latent heat flux. MM5-CLM3 produced very slight decreases in latent heat flux in parts of the Central Valley with the addition of non-irrigated agriculture.

In January, RSM produced a modest increase $\left(+5-20 \mathrm{~W} / \mathrm{m}^{2}\right)$ in sensible heat flux where irrigated agriculture replaced forest or woodland vegetation (in northern California and Oregon), coincident with the decrease in January latent flux. RSM also produced a large decrease in January sensible heat flux in the Imperial Valley (by more than $40 \mathrm{~W} / \mathrm{m}^{2}$ ), in association with the increase in latent flux there. RegCM3 and DRCM produced similar, but more modest decreases in sensible heat flux in the Imperial Valley, and had fewer changes elsewhere in the domain. MM5-CLM3 produced slight increases in January sensible heat flux in some areas where non-irrigated agriculture replaced woodland or forest. In August, with conversion of natural vegetation to irrigated agriculture, sensible heat flux decreased by $\sim 100 \mathrm{~W} / \mathrm{m}^{2}$ in both RSM and RegCM3 (Table 3), a change opposite in sign, but similar in magnitude to the change in latent heat flux. DRCM also produced large decreases in sensible heat flux in irrigated areas $\left(-76 \mathrm{~W} / \mathrm{m}^{2}\right)$. MM5-CLM3 produced modest decreases in August sensible heat flux in areas converted to non-irrigated agriculture in the MOD case, likely a result of changes in canopy properties such as albedo (Table 2).

January relative humidity produced by the four models ranged from $30 \%-100 \%$, with the lowest values in the southeast corner of the domain. Between MOD and NAT cases, the only difference in January relative humidity was a modest increase $(10 \%-30 \%)$ over the Imperial Valley with the addition of irrigation in RSM and RegCM3. In August, a dry part of the year in most of the modeled domain, RSM and RegCM3 both produced strong increases in relative humidity in irrigated areas, with a more pronounced effect in RSM $(+36 \%)$ than in RegCM3 $(+23 \%)$ (Table 3$)$. DRCM produced a modest increase in relative humidity $(+9 \%)$, while MM5CLM3 produced no differences between the cases.

Temperature responses to the conversion of natural vegetation to irrigated cropland varied with model, with season, and with time of day. In January, RSM, RegCM3, and DRCM produced slight decreases $\left(-1^{\circ} \mathrm{C}\right.$, or $\left.-1.8^{\circ} \mathrm{F}\right)$ in Tmean in the Imperial Valley, with the largest change produced by RegCM3 (Figure 6). MM5-CLM3 produced slight decreases in January temperature in Idaho, where non-irrigated agriculture replaced mostly forest vegetation. In August, RSM, RegCM3, and DRCM produced temperature differences that were much more pronounced: Tmean was reduced by $1.4^{\circ} \mathrm{C}-3^{\circ} \mathrm{C}\left(2.5^{\circ} \mathrm{F}-5.4^{\circ} \mathrm{F}\right)$ averaged over all areas converted to irrigated agriculture, with the largest decreases occurring in the Central and Imperial Valleys in RegCM3 (Table 3). The cooling effect occurred not only in the grid cells that were irrigated in 

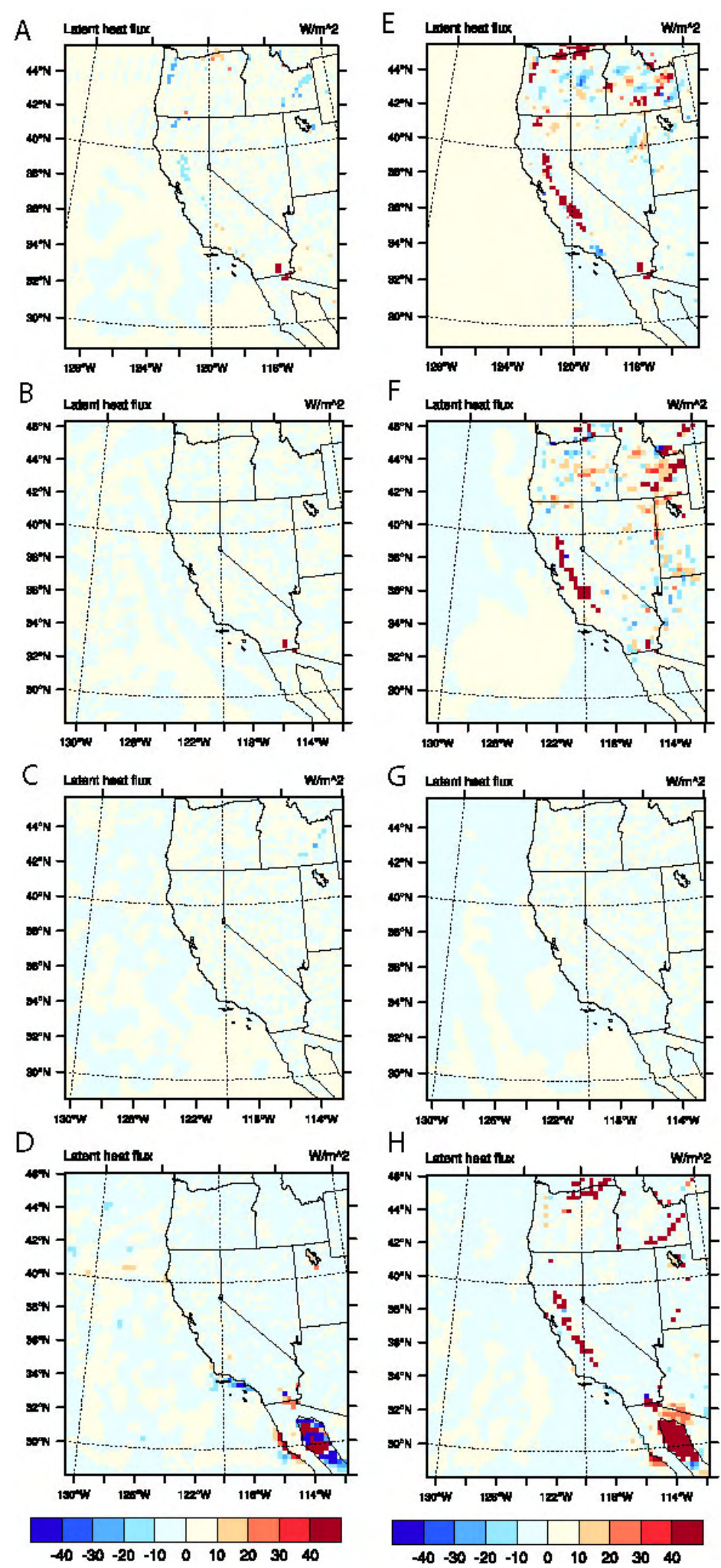

Figure 5. January and August latent heat flux anomalies (MOD minus NAT) in W/m². A. January RSM B. January RegCM3 C. January MM5-CLM3 D. January DRCM E. August RSM F. August RegCM3 G. August MM5-CLM3 H. August DRCM. 
the MOD case, but in adjacent grid cells as well (Figure 6). As a result, RSM, RegCM3, and DRCM produced substantially lower temperatures in much of inland central California and southeastern Idaho in the MOD case relative to the NAT case. MM5-CLM3 produced a very slight cooling in areas with non-irrigated agriculture in the MOD case in the Central Valley and Idaho, again reflecting the lack of supplemental soil water in this particular model run.

In the Imperial Valley, RSM, RegCM3, and DRCM produced lower January Tmax in the MOD case. In RegCM3 this effect was as large as $-4^{\circ} \mathrm{C}\left(-7.2^{\circ} \mathrm{F}\right)$. RSM and DRCM also produced cooler maximums in the Central Valley, but the reduction was relatively small (Table 3, 4). In August, RSM, RegCM3, and DRCM produced very large decreases in Tmax over all irrigated areas ( -3 to $-6^{\circ} \mathrm{C}$, or $-5.4^{\circ} \mathrm{F}$ to $\left.-10.8^{\circ} \mathrm{F}\right)$, and in the Central Valley $\left(-5\right.$ to $-8^{\circ} \mathrm{C}$, or $-9^{\circ} \mathrm{F}$ to $\left.-14.4^{\circ} \mathrm{F}\right)($ Table 3,4$)$. As with Tmean, the cooling effect extended well beyond the grid cells designated as agricultural land. As a consequence, Tmax values averaged over the Central Valley of California were $28^{\circ} \mathrm{C}-$ $31^{\circ} \mathrm{C}\left(82^{\circ} \mathrm{F}-88^{\circ} \mathrm{F}\right)$ in the MOD case, instead of $33^{\circ} \mathrm{C}-38^{\circ} \mathrm{C}\left(91^{\circ} \mathrm{F}-100^{\circ} \mathrm{F}\right)$. MM5-CLM3 produced slightly cooler maximum temperatures in southeastern Idaho in August, where non-irrigated agriculture replaced shrubland and grassland.

RSM produced increased January Tmin values of $1^{\circ} \mathrm{C}-4^{\circ} \mathrm{C}\left(1.8^{\circ} \mathrm{F}-7.2^{\circ} \mathrm{F}\right)$ in the Imperial and Central Valleys, an effect that is not replicated in the other models. In August, Tmin changes vary considerably among the models, with Tmin rising by $2^{\circ} \mathrm{C}\left(3.6^{\circ} \mathrm{F}\right)$ over all irrigated areas in $\mathrm{RSM}$, declining $1^{\circ} \mathrm{C}\left(1.8^{\circ} \mathrm{F}\right)$ over all irrigated areas in RegCM3, and declining $1^{\circ} \mathrm{C}\left(1.8^{\circ} \mathrm{F}\right)$ over areas designated as irrigated croplands (but without soil water supplements) in MM5-CLM3 (Table 3). DRCM produced no discernible effect on August Tmin values with the conversion of natural vegetation to irrigated agriculture.

Reflecting the changes in Tmin and Tmax, RSM produced decreases in January mean DTR of $2^{\circ} \mathrm{C}\left(3.6^{\circ} \mathrm{F}\right)$ in the Central Valley, while RegCM3, MM5-CLM3, and DRCM produced more muted decreases $\left(-0.2\right.$ to $0.3^{\circ} \mathrm{C}$, or $-0.36^{\circ} \mathrm{F}$ to $\left.0.54^{\circ} \mathrm{F}\right)$. In August, RSM, RegCM3, and DRCM produced substantial decreases in DTR between cases, averaged over all irrigated areas. The effect was most pronounced in RSM, with a decrease of $8^{\circ} \mathrm{C}\left(14.4^{\circ} \mathrm{F}\right)$ in the Central Valley (Table 3). MM5-CLM3, which did not supplement soil moisture, produced a modest $\left(1^{\circ} \mathrm{C}\right.$, or $\left.1.8^{\circ} \mathrm{F}\right)$ increase in DTR.

There was a pronounced seasonal cycle in the magnitude of the climate effects of supplementing soil moisture to mimic irrigation in the models. While DRCM applied a temperature criterion to determining when to irrigate, both RSM and RegCM3 supplemented soil moisture at every time step throughout the year. Nonetheless, due to seasonal variation in precipitation and solar radiation, the resulting differences in soil moisture between the cases were minimal between December and February, and most pronounced from June to September across all three models, particularly in the Central Valley (Figure 7). The seasonal variation in latent heat flux, Tmax, and Tmin differences follows the soil moisture pattern, with more muted variation (and diverging model responses to irrigation) for Tmin (Figure 7). MM5-CLM3, which did not supplement soil moisture, produced very little change throughout the year for the same variables, reinforcing the large influence of soil moisture, and relatively small influence of other canopy properties, on climate in the Central Valley region (Figure 7). 

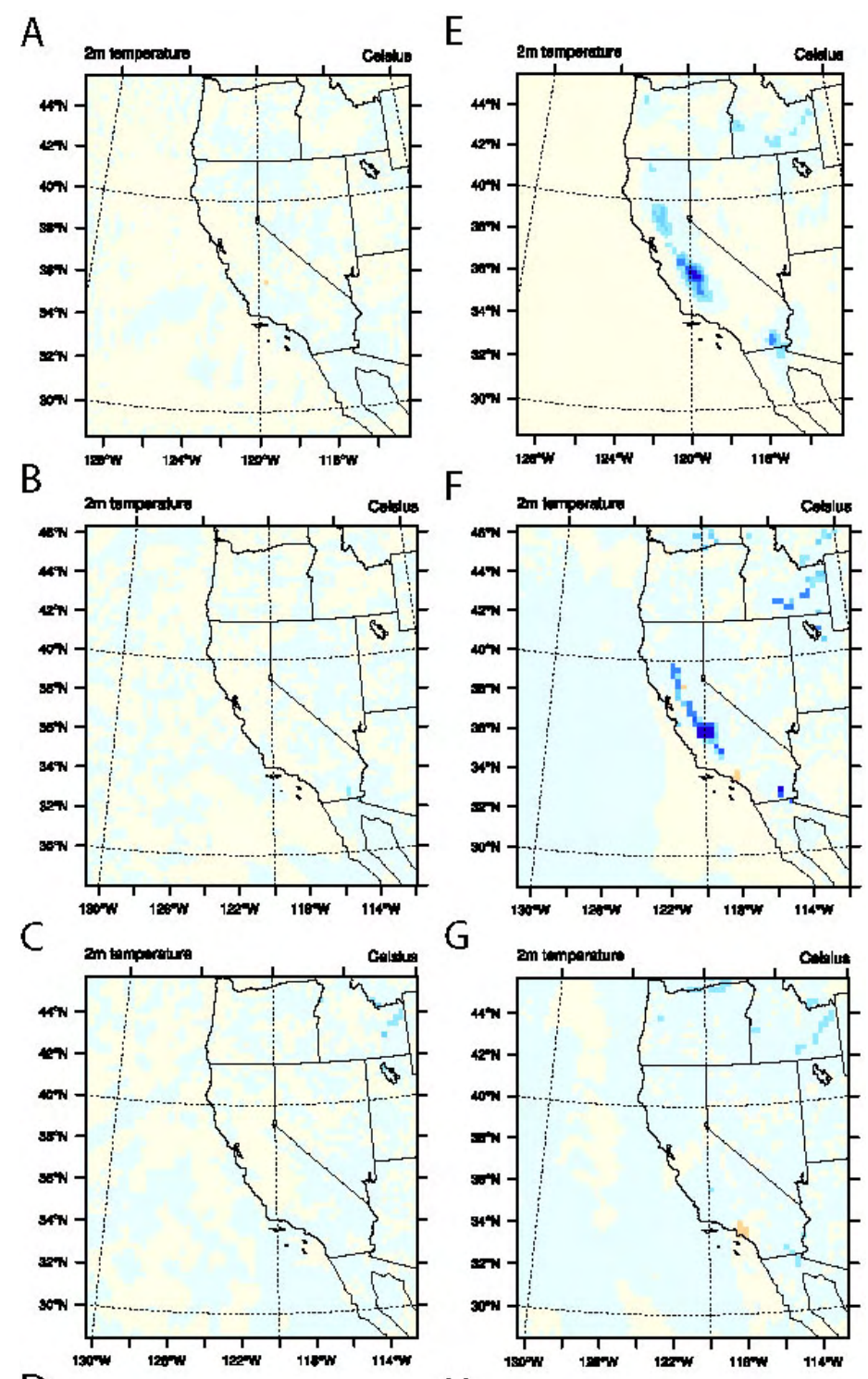

$\mathrm{G}$
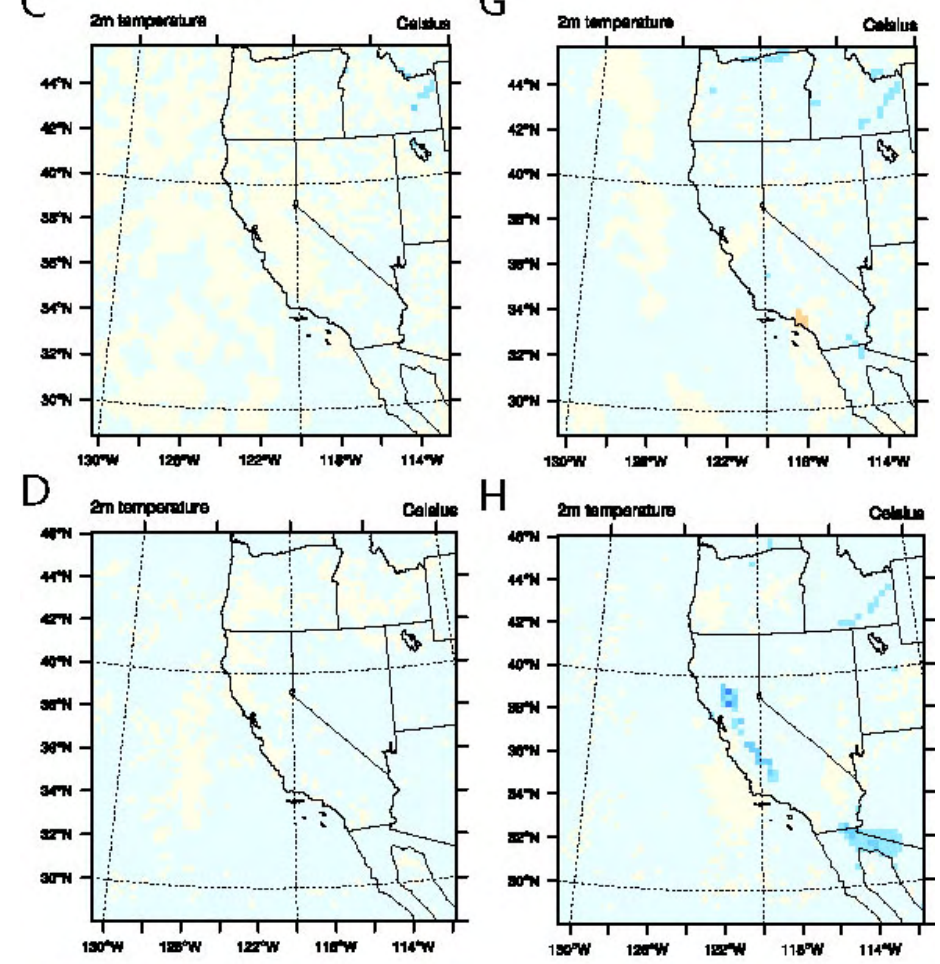

$\begin{array}{ccccccccccc}-5 & -4 & -3 & -2 & -1 & 0 & 1 & 2 & 3 & 4 & 5\end{array}$

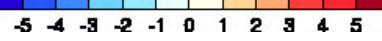

Figure 6. January and August mean 2-meter temperature anomalies (MOD minus NAT) $\left({ }^{\circ} \mathrm{C}\right)$. A. January RSM B. January RegCM3 C. January MM5-CLM3 D. January DRCM E. August RSM F. August RegCM3 G. August MM5-CLM3 H. August DRCM. 


\subsection{Effects of Converting Natural Vegetation to Urban Land Cover}

Changes in key near-surface variables were also examined for areas that were converted from natural land cover types to the urban type. Again, results are reported for MOD - NAT cases and as monthly averages for January and August. First, the report examines results for all urban areas in the model domains, and then for the greater Los Angeles region only.

A

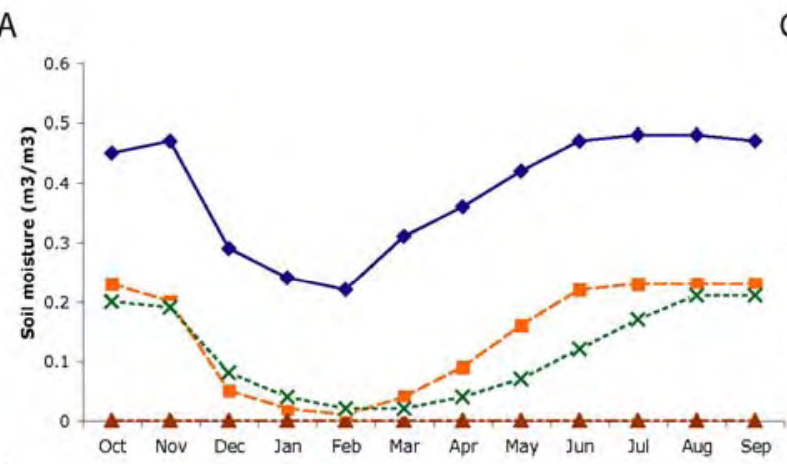

C

B
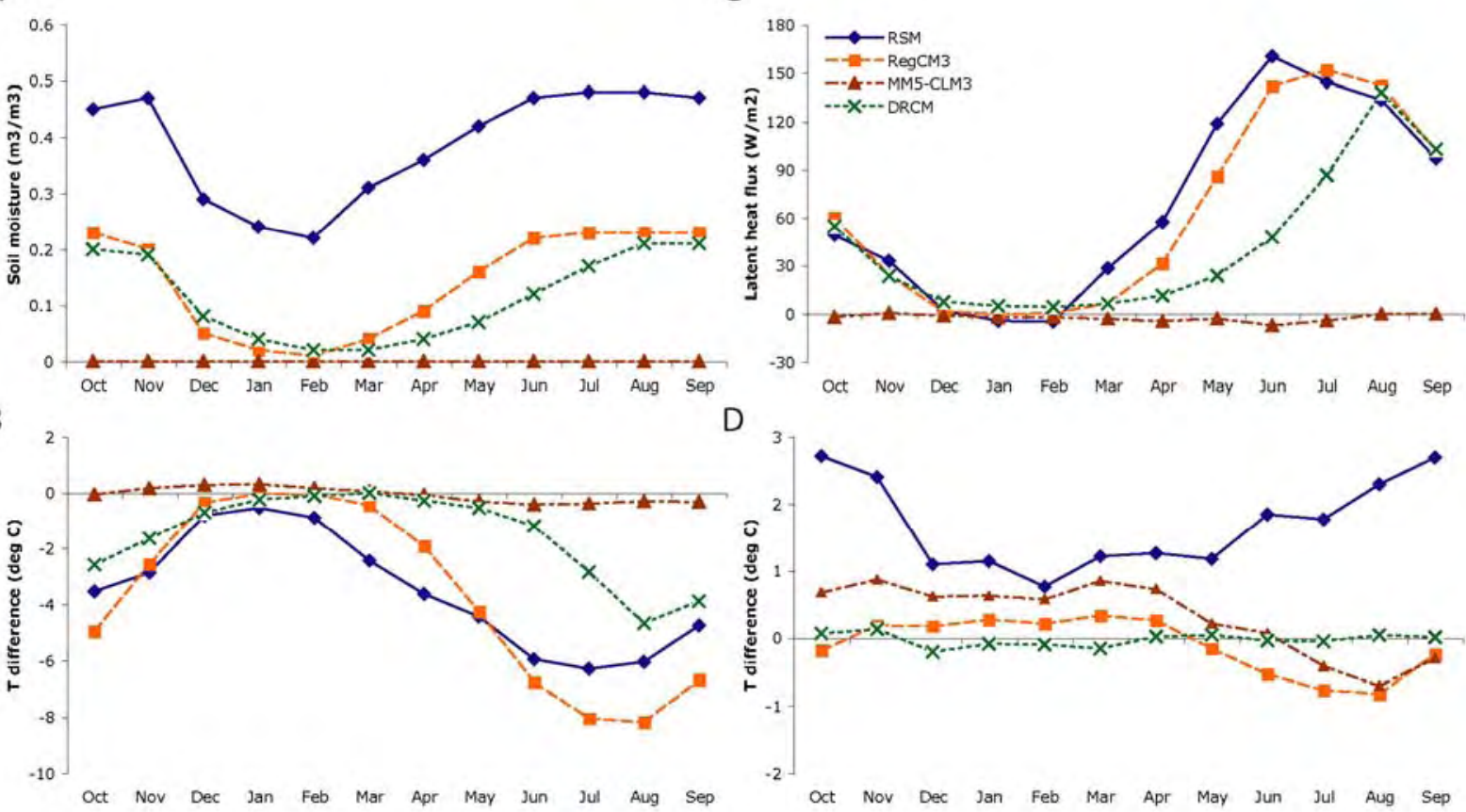

Figure 7. Monthly variation in climate differences between MOD and NAT averaged over irrigated agriculture in the Central Valley for the four models. A. Monthly soil moisture anomalies $(\mathrm{m} 3 / \mathrm{m} 3) \mathrm{B}$. Monthly maximum 2-meter temperature anomalies $\left({ }^{\circ} \mathrm{C}\right) \mathrm{C}$. Monthly latent heat flux anomalies (W/m2) D. Monthly minimum 2-meter temperature anomalies $\left({ }^{\circ} \mathrm{C}\right)$.

\subsection{All Urban Areas}

The climate effects of converting natural vegetation to urban land cover were smaller and more diverse than the effects of converting natural vegetation to irrigated agriculture, due to the considerable variation in how urban land was parameterized among the models. In January, the amount of soil moisture increased where urban areas replaced natural vegetation in RegCM3 and RSM (3.5-20.7 mm, or 0.14-0.8 in), while in MM5-CLM3 there was little change (0.5 mm, or $0.02 \mathrm{in}$ ), and in DRCM soil moisture decreased (-10.1 mm, or $-0.4 \mathrm{in}$ ) (Figure 4, Table 5). In all four models, January latent heat flux decreased slightly $\left(-2.8-8.6 \mathrm{~W} / \mathrm{m}^{2}\right)$ (Figure 5), while sensible heat flux increased in RSM, RegCM3, and DRCM (4-10 W/ $\left.\mathrm{m}^{2}\right)$, and decreased in MM5CLM3 $\left(-5.0 \mathrm{~W} / \mathrm{m}^{2}\right)$. Relative humidity decreased in RegCM3, RSM, and DRCM (-1.1\%-2.8\%) and increased in MM5-CLM3 (0.9\%). Tmean increased slightly in RegCM3, RSM, and DRCM $\left(0.1^{\circ} \mathrm{C}-0.5^{\circ} \mathrm{C}\right.$, or $\left.0.18^{\circ} \mathrm{F}-0.9^{\circ} \mathrm{F}\right)$ and decreased in MM5-CLM3 $\left(-0.2^{\circ} \mathrm{C}\right.$, or $\left.-0.36^{\circ} \mathrm{F}\right)$ (Figure 6, Table 5). In RSM, RegCM3, and DRCM Tmax increased $\left(0.2^{\circ} \mathrm{C}-0.7^{\circ} \mathrm{C}\right.$, or $\left.0.36^{\circ} \mathrm{F}-1.3^{\circ} \mathrm{F}\right)$ while there was a decrease in $\operatorname{Tmax}\left(-0.5^{\circ} \mathrm{C}\right.$, or $\left.-0.9^{\circ} \mathrm{F}\right)$ in MM5-CLM3. January Tmin increased in RSM and 
RegCM3 $\left(0.2^{\circ} \mathrm{C}-0.5^{\circ} \mathrm{C}\right.$, or $\left.0.36^{\circ} \mathrm{F}-0.9^{\circ} \mathrm{F}\right)$ and decreased in MM5-CLM3 and DRCM $\left(-0.1^{\circ} \mathrm{C}-0.2^{\circ} \mathrm{C}\right.$, or $\left.-0.18^{\circ} \mathrm{F}-0.36^{\circ} \mathrm{F}\right)$.

Table 5. Change in near surface climate variables between potential NAT vegetation and MOD vegetation cases spatially average over all urban land in the model domains. The number of grid cells for All urban, RegCM3: 11, RSM: 18, MM5-CLM3: 11 DRCM: 11. Variables and units as in Table 3.

\begin{tabular}{|l|r|r|r|r|r|r|r|r|}
\hline & \multicolumn{7}{l}{ Jan } \\
\hline Variable & \multicolumn{1}{l}{ RSM } & RegCM3 & $\begin{array}{l}\text { MM5- } \\
\text { CLM3 }\end{array}$ & DRCM & RSM & RegCM3 & $\begin{array}{l}\text { MM5- } \\
\text { CLM3 }\end{array}$ & DRCM \\
\hline Tmean & 0.2 & 0.5 & -0.4 & 0.1 & 0.3 & 1.1 & 0.8 & -0.3 \\
\hline Tmax & 0.2 & 0.7 & -0.5 & 0.3 & 0.6 & 1.0 & -0.4 & 0.1 \\
\hline Tmin & 0.2 & 0.5 & -0.1 & -0.2 & 0.3 & 1.0 & 2.0 & -0.5 \\
\hline DTR & 0.1 & 0.2 & -0.4 & 0.5 & 0.3 & 0.0 & -2.4 & 0.6 \\
\hline LHFS & -3.8 & -5.0 & -2.8 & -8.6 & -18.0 & -15.3 & -2.9 & -9.4 \\
\hline SHFS & 4.0 & 10.0 & -5.0 & 8.6 & 17.2 & 17.2 & -45.6 & 25.4 \\
\hline SMT & 3.5 & 20.7 & 0.5 & -10.1 & 3.7 & 14.1 & 2.1 & -5.0 \\
\hline RHS & -1.1 & -2.8 & 0.9 & -1.3 & -0.1 & -3.1 & -0.6 & 1.1 \\
\hline
\end{tabular}

In August, soil moisture increased where urban areas replaced natural vegetation in RegCM3, MM5-CLM3, and RSM (2.1-14.1 mm, or 0.08-0.56 in) but decreased in DRCM (-5.0 mm, or $-0.2 \mathrm{in}$ ) (Figure 4, Table 5). Latent heat flux decreased in all four models by up to $-18 \mathrm{~W} / \mathrm{m}^{2}$ (Figure 5), while sensible heat flux increased in RegCM3, RSM, and DRCM by up to $30 \mathrm{~W} / \mathrm{m}^{2}$, but decreased in MM5-CLM3 by $17 \mathrm{~W} / \mathrm{m}^{2}$. In RSM, RegCM3, and MM5-CLM3 relative humidity decreased (-0.1\%-3.1\%), but increased in DRCM (1.1\%). Tmean in August increased in MOD relative to NAT by up to $1^{\circ} \mathrm{C}\left(1.8^{\circ} \mathrm{F}\right)$ in all models except DRCM where Tmean decreased $\left(-0.3^{\circ} \mathrm{C}\right.$, or $\left.-0.5^{\circ} \mathrm{F}\right)$ (Figure 6). Tmax increased in RSM, RegCM3, and DRCM $\left(0.1^{\circ} \mathrm{C}-1.0^{\circ} \mathrm{C}\right.$, or $\left.0.18^{\circ} \mathrm{F}-1.8^{\circ} \mathrm{F}\right)$, while decreasing in MM5-CLM3 $\left(-0.4^{\circ} \mathrm{C}\right.$, or $\left.-0,7^{\circ} \mathrm{F}\right)$ (Table 5$)$. Tmin increased in RSM, RegCM3, and MM5-CLM3 $\left(0.3^{\circ} \mathrm{C}-2.0^{\circ} \mathrm{C}\right.$, or $\left.0.5^{\circ} \mathrm{F}-3.6^{\circ} \mathrm{F}\right)$, while decreasing in DRCM ($0.5^{\circ} \mathrm{C}$, or $\left.-0.9^{\circ} \mathrm{F}\right)$. In RSM and DRCM temperature range increased $\left(0.3-0.6^{\circ} \mathrm{C}\right.$, or $\left.0.5^{\circ} \mathrm{F}-1.1^{\circ} \mathrm{F}\right)$, was unchanged in RegCM3, and decreased in MM5-CLM3 $\left(-2.4^{\circ} \mathrm{C}\right.$, or $\left.-4.3^{\circ} \mathrm{F}\right)$.

\subsection{Los Angeles Area}

The greater Los Angeles Area covers about 88,000 km² (55,000 mi²), with the highest-density area represented by 5-11 grid cells in the four models (including San Diego in some cases). Los Angeles (LA) is examined here because it has the largest population density in the western United States. In January, where urban land replaced natural vegetation, soil moisture increased in RSM, RegCM3, and MM5-CLM3 (2.1-14.1 mm, or 0.2-0.6in) while decreasing in DRCM (-6.2 mm, or $-0.2 \mathrm{in)} \mathrm{(Table} \mathrm{6).} \mathrm{In} \mathrm{all} \mathrm{four} \mathrm{models,} \mathrm{latent} \mathrm{heat} \mathrm{flux} \mathrm{decreased} \mathrm{by}$ -0.9-11.2 W/ $\mathrm{m}^{2}$ in January. Sensible heat flux increased in RegCM3, RSM, and DRCM (2.7-12.7 W/ $\left.\mathrm{m}^{2}\right)$ and decreased in MM5-CLM3 (-8.4 W/m²). In RegCM3, RSM, and MM5-CLM3 
relative humidity decreased $(-0.1 \%-3.1 \%)$ but increased in DRCM $(1.1 \%)$. Tmean increased in $\operatorname{RSM}\left(0.2^{\circ} \mathrm{C}\right.$, or $\left.0.4^{\circ} \mathrm{F}\right)$ and $\operatorname{RegCM} 3\left(0.4^{\circ} \mathrm{C}\right.$, or $\left.0.7^{\circ} \mathrm{F}\right)$, but decreased in MM5-CLM3 $\left(-0.5^{\circ} \mathrm{C}\right.$, or $-0.9^{\circ} \mathrm{F}$ ) and DRCM $\left(-0.1^{\circ} \mathrm{C}\right.$, or $\left.-0.18^{\circ} \mathrm{F}\right)$ (Table 6). Tmax increased in RSM, DRCM, and RegCM3 $\left(0.3^{\circ} \mathrm{C}-0.8^{\circ} \mathrm{C}\right.$, or $\left.0.5^{\circ} \mathrm{F}-1.4^{\circ} \mathrm{F}\right)$ in January, and decreased in MM5-CLM3 $\left(-0.7^{\circ} \mathrm{C}\right.$, or $\left.-1.3^{\circ} \mathrm{F}\right)$. Tmin increased slightly in RSM and RegCM3 $\left(0.1^{\circ} \mathrm{C}-0.3^{\circ} \mathrm{C}\right.$, or $\left.0.2^{\circ} \mathrm{F}-0.5^{\circ} \mathrm{F}\right)$ and decreased in MM5-CLM3 and DRCM $\left(-0.1^{\circ} \mathrm{C}-0.2^{\circ} \mathrm{C}\right.$, or $\left.-0.2^{\circ} \mathrm{F}-0.4^{\circ} \mathrm{F}\right)$. DTR increased in RSM, RegCM3, and DRCM $\left(0.2^{\circ} \mathrm{C}-0.5^{\circ} \mathrm{C}\right.$, or $\left.0.4^{\circ} \mathrm{F}-0.9^{\circ} \mathrm{F}\right)$ and decreased in MM5-CLM3 $\left(-0.5^{\circ} \mathrm{C}\right.$, or $\left.-0.9^{\circ} \mathrm{F}\right)$.

Table 6. Change in near surface climate variables between potential NAT vegetation and MOD vegetation cases spatially average over Los Angeles area urban land. The number of grid cells for LA urban, RegCM3: 5, RSM: 11, MM5-CLM3: 7. Variables and units as in Table 3.

\begin{tabular}{|l|r|r|r|r|r|r|r|r|}
\hline & \multicolumn{7}{|l}{ Jan } & \multicolumn{7}{l|}{ Aug } \\
\hline Variable & \multicolumn{1}{|l}{ RSM } & RegCM3 & $\begin{array}{l}\text { MM5- } \\
\text { CLM3 }\end{array}$ & DRCM & RSM & RegCM3 & $\begin{array}{l}\text { MM5- } \\
\text { CLM3 }\end{array}$ & DRCM \\
\hline Tmean & 0.2 & 0.4 & -0.5 & -0.1 & 0.5 & 1.1 & 1.1 & -0.2 \\
\hline Tmax & 0.3 & 0.8 & -0.7 & 0.3 & 1.1 & 1.2 & -0.4 & -0.1 \\
\hline Tmin & 0.1 & 0.3 & -0.1 & -0.2 & 0.3 & 1.0 & 2.6 & -0.1 \\
\hline DTR & 0.2 & 0.5 & -0.5 & 0.5 & 0.8 & 0.3 & -3.0 & -0.1 \\
\hline LHFS & -2.9 & -4.4 & -0.9 & -11.2 & -17.5 & -1.2 & -2.2 & -1.0 \\
\hline SHFS & 2.7 & 9.0 & -8.4 & 12.7 & 20.0 & 8.6 & -49.4 & 15.2 \\
\hline SMT & 5.2 & 11.3 & 0.8 & -6.2 & 4.0 & 11.1 & 2.3 & -1.2 \\
\hline RHS & -0.5 & -2.1 & 1.7 & -1.2 & -1.0 & -1.8 & -0.9 & 0.8 \\
\hline
\end{tabular}

Over the LA region, soil moisture increased in RegCM3, RSM, and MM5-CLM3 (2.3-11.1 mm, or $0.1-0.44 \mathrm{in})$ and decreased in DRCM $(-1.2 \mathrm{~mm}$, or $-0.05 \mathrm{in})$ in August (Table 6). Latent heat flux decreased slightly in August in RegCM3, MM5, and DRCM (-1.0-2.2 W/m²), and greatly decreased in RSM by $-17.5 \mathrm{~W} / \mathrm{m}^{2}$. Sensible heat flux increased in RegCM3, RSM, and DRCM $\left(8.6-20.0 \mathrm{~W} / \mathrm{m}^{2}\right)$ and decreased in MM5-CLM3 $\left(-49.4 \mathrm{~W} / \mathrm{m}^{2}\right)$ in August. Relative humidity decreased in RSM, RegCM3, and MM5-CLM3 (-0.9\%-1.8\%) and increased in DRCM (0.8\%). Tmean increased in RSM, RegCM3, and MM5-CLM3 in August $\left(0.5^{\circ} \mathrm{C}-1.1^{\circ} \mathrm{C}\right.$, or $\left.0.9^{\circ} \mathrm{F}-1.9^{\circ} \mathrm{F}\right)$ and decreased in DRCM $(-0.2 \mathrm{C}$, or $-0.4 \mathrm{~F})$ where urban land cover replaced the natural vegetation (Table 6). While Tmax increased in RegCM3 and RSM $\left(0.5^{\circ} \mathrm{C}-1.1^{\circ} \mathrm{C}\right.$, or $\left.0.9^{\circ} \mathrm{F}-1.9^{\circ} \mathrm{F}\right)$, there was a decrease in Tmax in MM5-CLM3 and DRCM $\left(-0.1^{\circ} \mathrm{C}-0.4^{\circ} \mathrm{C}\right.$, or $\left.-0.18^{\circ} \mathrm{F}-0.7^{\circ} \mathrm{F}\right)$. Tmin increased in MM5-CLM3 by $2.6^{\circ} \mathrm{C}\left(4.7^{\circ} \mathrm{F}\right)$ in August, with smaller increases in RegCM3 and $\operatorname{RSM}\left(0.3^{\circ} \mathrm{C}-1.0^{\circ} \mathrm{C}\right.$, or $\left.0.5^{\circ} \mathrm{F}-1.8^{\circ} \mathrm{F}\right)$ and a decrease in DRCM $\left(-0.1^{\circ} \mathrm{C}\right.$, or $\left.-0.18^{\circ} \mathrm{F}\right)$. As a result of these changes in Tmax and Tmin, the DTR in August increased in RegCM3 and RSM $\left(0.3^{\circ} \mathrm{C}-\right.$ $0.8^{\circ} \mathrm{C}$, or $\left.0.5^{\circ} \mathrm{F}-1.4^{\circ} \mathrm{F}\right)$, and decreased in MM5-CLM3 and DRCM $\left(-0.1^{\circ} \mathrm{C}-3.0^{\circ} \mathrm{C}\right.$, or $\left.-0.18^{\circ} \mathrm{F}-0.5^{\circ} \mathrm{F}\right)$. 


\subsection{Discussion}

\subsection{Irrigated Agriculture}

In the three models that supplemented soil moisture to higher levels under irrigated agriculture (RSM, RegCM3, and DRCM), changes in surface climate largely consistent with simple physical arguments were found. Increasing soil moisture under irrigated crops led to a shift from sensible to latent heat flux, which in turn resulted in lower average and maximum surface temperatures. It also resulted in substantially higher relative humidity. The magnitude of the irrigation effect differed among the models, reflecting differences in how the models altered soil moisture, in the sensitivity of temperature variables to the enhanced moisture availability, and in other land surface properties such as soil texture, soil thermal diffusion, and albedo. Contrary to expectations, RegCM3 produced a larger average effect on $2 \mathrm{~m}(6.6 \mathrm{ft})$ mean and maximum temperatures between June and September than did RSM, even though RSM forced soil moisture to a higher level (saturation, all soil pore space is filled with water) than RegCM3 (field capacity, soil pore space partially filled with water). This is in spite of the fact that latent heat flux differences are similar between RSM and RegCM3, and sensible heat flux differences are larger in RSM. In the three models that enhanced soil moisture under irrigated cropland, the largest climate effects were found during the summer (dry) months of July and August for all variables, with some differences persisting until December or beginning as early as March. The largest decreases in Tmean occurred over California's Central and Imperial Valleys. Tmax dropped even more than Tmean with conversion to irrigated agriculture, by $-6.1^{\circ} \mathrm{C}\left(-11^{\circ} \mathrm{F}\right)$ in RSM, $-8.2^{\circ} \mathrm{C}\left(-14.8^{\circ} \mathrm{F}\right)$ in RegCM3, and $-4.7^{\circ} \mathrm{C}\left(-8.5^{\circ} \mathrm{F}\right)$ in DRCM in August in the Central Valley. The changes in Tmean are comparable in magnitude but opposite in sign to temperature changes predicted for future increases in greenhouse gas concentrations in this region (Snyder and Sloan, 2005). However, compared to the CRU observations, the models produced Tmean and Tmax values that were too cool in the Central Valley in August, indicating that the models may be over-estimating the amount of irrigation water in the soils in this area. The irrigation effects on relative humidity and temperatures were strongest in the irrigated grid cells, but were also detected in adjacent grid cells. Tmax was affected up to three grid cells $(75 \mathrm{~km}$, or $47 \mathrm{mi}$ ) away.

The models differed in the sensitivity of Tmin to the conversion to irrigated agriculture. RSM produced an increase in August Tmin of up to $2^{\circ} \mathrm{C}\left(3.6^{\circ} \mathrm{F}\right)$, while RegCM3 produced a decrease of $1^{\circ} \mathrm{C}\left(1.8^{\circ} \mathrm{F}\right)$ averaged over all irrigated areas. These effects were more pronounced in the Central Valley in RSM, and less pronounced overall in DRCM. In RSM and RegCM3, nighttime sensible heat flux was negative (net heat uptake by the ground surface) in the NAT case, indicating that the ground was colder than the air. Under irrigation, nighttime sensible heat flux was even more negative in RegCM3, perhaps because daytime heating was reduced due to the increased moisture availability and shift from sensible to latent heat flux. In RSM, nighttime latent heat flux was negative, indicating that warming minimum temperatures were due to condensation and release of latent heat to the lower atmosphere. The additional water vapor in the MOD case resulted in a higher dewpoint temperature, which limited nighttime cooling. Less daytime heating of the soil surface and higher dewpoint temperatures should occur in both models, but in RSM the latter process won out, due to the saturated soil prescribed for irrigated

agriculture. In addition, differences in soil thermal properties and natural vegetation types between the models may help explain the differences in response among the models. 
Christy et al. (2006) present an analysis of observations in the southern portion of the California Central Valley (San Joaquin Valley) showing that the temperature changes during the twentieth century have been fairly large, and seasonally consistent, increases in Tmin and only small decreases in Tmax in the summer months. The authors' interpretation of the observations attributes these temperature changes to expanding irrigation over time. However, the present model simulations produce relatively small increases (or decreases) in Tmin and large decreases in Tmax. There are at least three factors that may help to explain this disparity. First, no greenhouse gas effects were included in the model simulations, but such effects would have influenced the observational records. Greater greenhouse gas concentrations would have dampened the decreases in Tmax produced by the models, enhanced any warming in Tmin, and dampened or reversed cooling of Tmin in the models. Second, the radiative effects of aerosols were not included in the model simulations. Buildup of aerosols near the surface from farm activities, vehicle emissions, and industrial sources could have increased the trapping of outgoing infrared radiation (IR) at night and raised Tmin in the observed temperature series, but not in the models. Finally, the models may differ in their representation of nighttime shallow boundary layer structure. A realistically shallow boundary layer would amplify any aerosol effect and possibly increase near surface humidity, leading to less nighttime IR loss. Lack of this structure in models would minimize this nighttime effect.

The modeled surface climate response to the conversion of natural vegetation to irrigated agriculture reported here is consistent with previous modeling studies in other semi-arid regions (e.g., Adegoke et al., 2003; Boucher et al., 2004). However, unlike some other studies (Barnston and Schickedanz, 1984; Schar et al., 1999; Segal et al., 1998) this study found no discernable effects on precipitation (data not shown). This discrepancy may be explained by the fact that precipitation along the west coast of the United States is very much a winter season phenomena, controlled by large-scale weather systems, with very little convective precipitation. The largest land use impacts appear to be in summer, when precipitation only rarely occurs in most of the western United States. One-week continental-scale model runs show precipitation changes elsewhere in the United States with the addition of irrigation, but no or negligible changes in the western-most states (Segal et al., 1998).

Although this study found no discernible difference in precipitation between cases, it did find that RSM and RegCM3 produced slight increases in surface pressure over irrigated areas, which led to small effects on surface winds. With the surface air temperature cooling in the MOD case, the surface pressure increased up to 0.6 hectopascals (hPa) in RSM, and up to $1 \mathrm{hPa}$ in RegCM3 in August. As a result, the westerlies into the Central Valley weakened. There were few changes in pressure height and wind above $850 \mathrm{hPa}$. These surface pressure and wind changes were the only impacts on the local atmospheric dynamics due to the land use changes, and these effects seem to be confined to the boundary layer. The land use changes did not affect cloudiness or incoming solar radiation at the surface.

This paper focuses on surface climate impacts, but theory predicts that the large changes in the surface energy and water budgets should affect the temperature and water vapor profiles through the lower atmosphere. Globally, the addition of water vapor to the upper troposphere could have a warming effect due to the radiative properties of water vapor (Boucher et al., 2004). Thus irrigation may result in substantial local and regional cooling, but contribute to global warming. Recent efforts to examine the global climate effects of future land cover change 
find large regional effects, but no net global climate effect, without added irrigation (Feddema et al., 2005). These papers and our findings reinforce the need to accurately incorporate land cover and land use change, including irrigation, into simulations of future climate.

\subsection{Urban}

Changing from a natural landscape to one with urban land cover leads to measurable changes in climate. Urban land cover typically has a lower albedo than the natural land cover it replaces (Sailor, 1995). A lower albedo increases the amount of solar radiation that is absorbed. This study found that in RegCM3 and RSM this increased absorption increased the sensible heat flux at the surface. In RegCM3 and RSM, the increased sensible heat flux lead to increased Tmax, Tmean, and Tmin. In August, DTR also increased because the increase in Tmax was greater than the increase in Tmin for both models. In MM5-CLM3, sensible heat flux was substantially decreased, because urban land was represented as bare (and highly reflective) soil in this model. Tmax decreased while Tmin increased by a greater amount, and the overall temperature range decreased. While all three models produced an increase in minimum temperature, MM5-CLM3 produced the greatest increase of $2^{\circ} \mathrm{C}\left(3.6^{\circ} \mathrm{F}\right)$ in August. One possible explanation for the large warming in Tmin in MM5-CLM3 is that more heat was stored in the ground and released back into the atmosphere at night due to the removal of vegetation, and therefore shading, from the urban land cover type. Latent heat flux was decreased in all models due to the removal (RSM) or decrease in the amount (RegCM3, MM5-CLM3, DRCM) of vegetation in the urban land cover type. Stomatal resistance was also increased in some models (RSM, RegCM3) reducing transpiration, and thus latent heat flux. Finally, RegCM3 had less permeable soil under urban land and DRCM limited the soil moisture levels, decreasing availability of soil water for evaporation. The decrease in latent heat flux was largest in the summer months. A previous model study found that varying the amount of soil moisture in the Los Angeles area had an effect on temperature and heat fluxes (Jacobson, 1999). As the four models in this study varied multiple land cover parameters simultaneously, the modeled changes cannot be directly compared to Jacobson's results.

The climate signal of changing land cover from natural vegetation to urban land was dependent upon both the parameterization of the urban land cover type and also the natural vegetation type that was replaced. Focusing in on the Los Angeles area in August this study found a range of climate responses in the four models (Figure 8). In RSM, the primary natural land cover type replaced was shrubland. The climate response was a large increase in sensible heat flux, and a corresponding increase in Tmax. The climate response in RegCM3 was more complex, as a patchwork of three different natural land cover types were replaced by urban land in this region. In the two northern grid cells, sensible heat flux decreased while Tmax decreased slightly in one gridcell, and increased in the other. In the two southern grid cells sensible heat flux increased and as a result Tmax also increased. The two northern grid cells are forest and shrubland, and have a lower albedo than the urban land cover type. In this case, changing from the natural to the urban land cover type resulted in the absorption of less radiation at the surface. However in the southern grid cells, semi-desert was replaced by a more absorptive urban land cover type, which leads to increased radiation absorption. In MM5-CLM3, the climate response was a consistently large decrease in sensible heat flux and a corresponding 

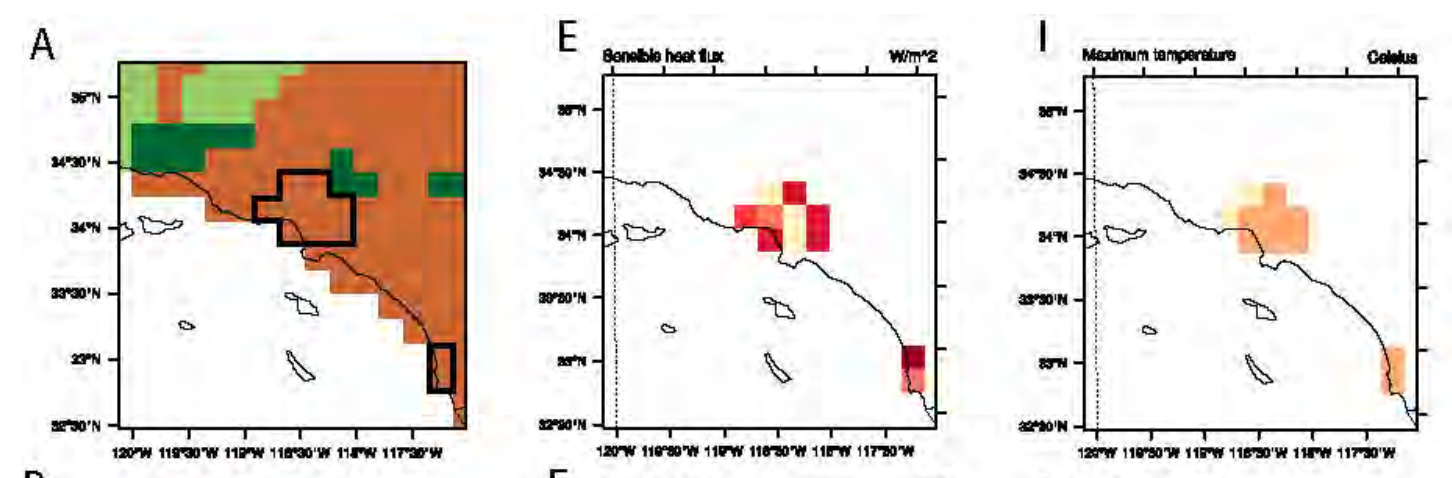

B
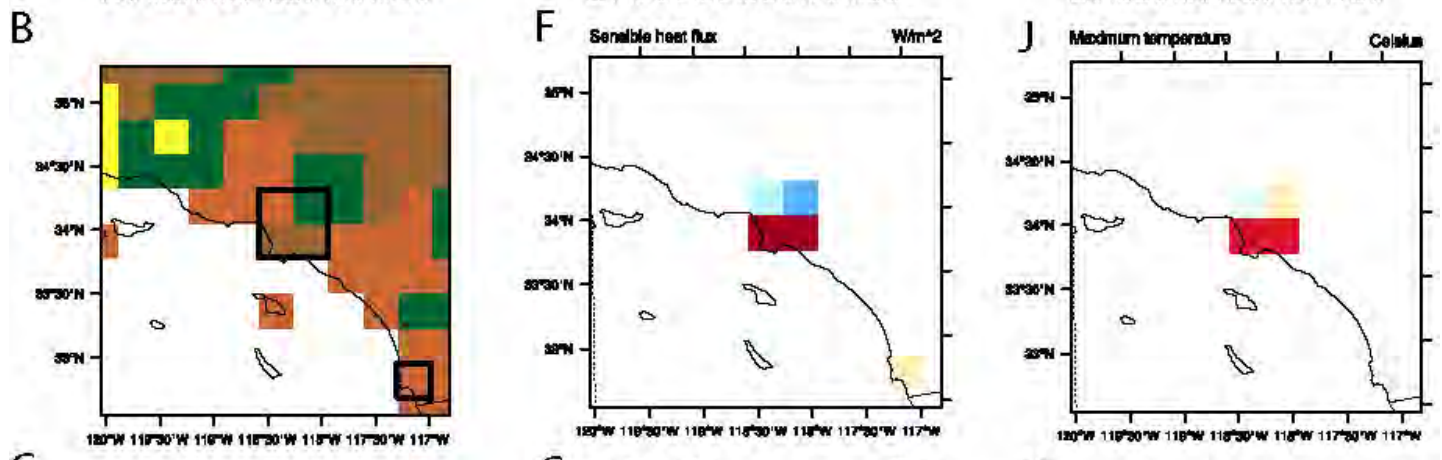

C
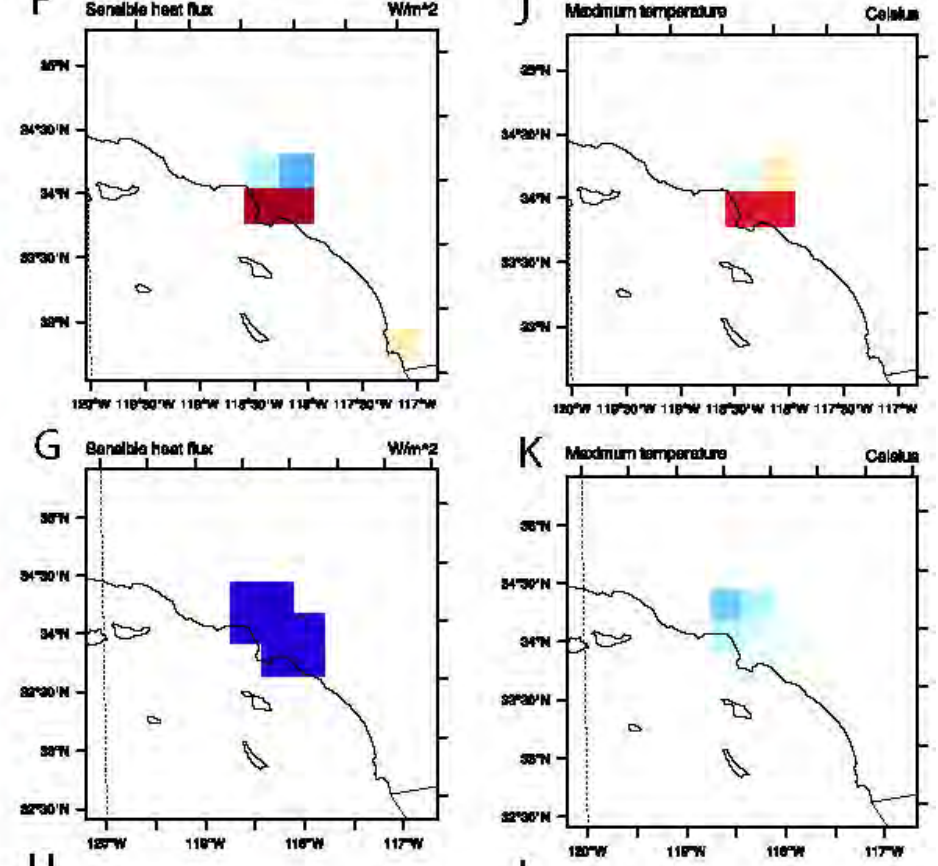

D
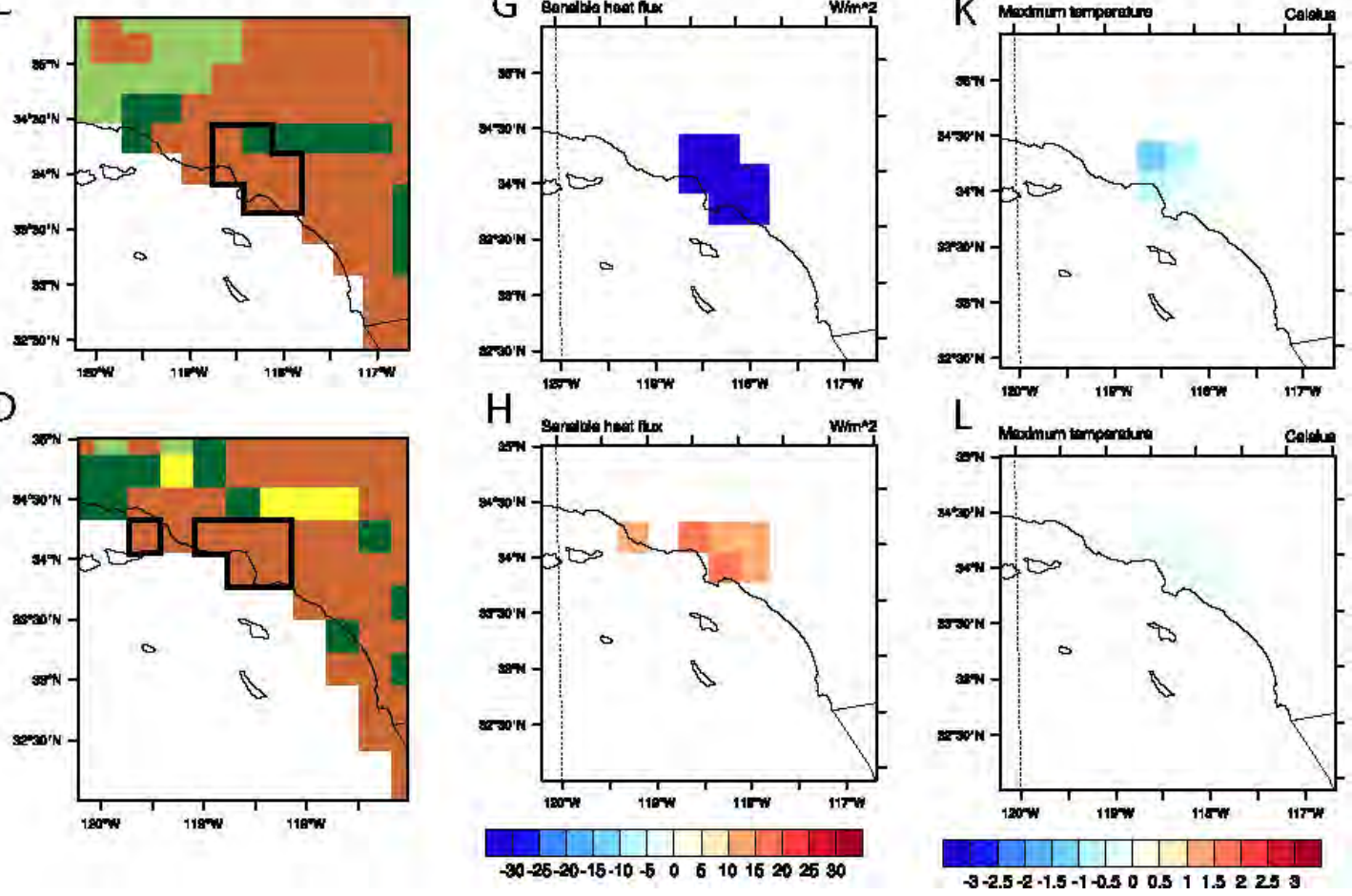

Figure 8. Los Angeles area NAT land cover with MOD urban areas outlined in black. August sensible heat flux $\left(\mathrm{W} / \mathrm{m}^{2}\right)$ and maximum temperature $\left({ }^{\circ} \mathrm{C}\right)$ anomalies (MOD minus NAT). A. RSM NAT vegetation and urban extent B. Same as A but for RegCM3 C. Same as A but for MM5-CLM3 D. Same as A but for DRCM E. RSM August sensible heat flux anomalies F. Same as E but for RegCM3 G. Same as E but for MM5-CLM3 H. Same as E but for DRCM I. RSM August 2-meter maximum temperature anomalies J. Same as I but for RegCM3 K. Same as I but for MM5-CLM3 L. Same as I but for DRCM. 
decrease in Tmax. Because MM5-CLM3 parameterizes urban land cover as bare ground with no vegetation, the urban type has a higher albedo than the shrubland type, which leads to a large reduction in radiation absorption. In the DRCM, for the urban land cover in the Los Angeles area, the only modification between the model cases is the fixed low soil moisture level. The lower soil moisture resulted in decreased latent, and increased sensible heat flux, and decreased Tmax. 


\subsection{Conclusions}

Land use is an important climate-forcing factor in the Western United States, particularly in the form of irrigated agricultural and urban land use. The size of the irrigation effect on surface temperature is comparable in magnitude but opposite in sign to temperature change predicted from increasing greenhouse gases in this region. Thus, agricultural land use represents an important forcing factor of climate that should be taken into consideration in all investigations of climate change, especially at a regional scale. The modeled effects of irrigation and urbanization are generally consistent across models, although differences for some variables due to model parameterizations do emerge. The nature of these model parameterizations needs to be assessed more thoroughly and refined through more detailed intercomparisons of physical processes, and through comparison with appropriate observational datasets. Comparison with atmospheric profiles of moisture, temperature, winds, and other variables should be undertaken to understand whether land use effects could be detected at higher altitudes as well. Observational datasets that are comprehensive enough to determine the energy and water balance of these regions would also be very useful for verifying the interpretation of model results.

One of the known shortcomings of this study is that several important diagnostic fields were not kept and accordingly, our discussion must implicitly assume that the effects of those unmonitored fields are minimum. These include incoming long wave radiation flux, net short wave radiation flux at the surface, ground heat flux, horizontal advection and vertical diffusion. Considering the very small impact on circulations in our experiments, the effect of the last two are probably very small but the first three can be significant sources of near surface temperature changes, since they are strongly affected by moisture content of atmosphere and land. Thus, for more complete understanding of the causes of the change in near surface temperature in our experiments, further refinements of the diagnostics are necessary.

The model results described here isolate the effects of converting natural vegetation to urban and irrigated agricultural land cover only. They do not include the indirect effects of urban and agricultural land use on climate via atmospheric loading of aerosols from industrial, transportation, or soil sources. Work by Jacobson (2004) and Rosenfeld and Givati (2005) has found that past additions of aerosols to California's atmosphere may have reduced incoming solar radiation and altered precipitation patterns. Further, as was discussed above, the models used fairly simple schemes to represent irrigation, probably overestimating the amount of water added to the soil in some regions and at some times of the year. Integrating available data on irrigation amounts and timing into future experiments will produce refined estimates. Finally, urban land cover parameterizations differed widely among the models, resulting in diverse and inconsistent climate impacts from conversion of natural vegetation to urban land. RCMs are run at a sufficiently high spatial resolution to capture major urban areas, and would benefit from an urban scheme designed to capture aggregate physical properties of urban areas, including anthropogenic heating, and their climate influences. 


\subsection{References}

Adegoke, J. O., R. A. S. Pielke, J. L. Eastman, R. Mahmood, and K. G. Hubbard. 2003. “Impact of irrigation on midsummer surface fluxes and temperature under dry synoptic conditions: A regional atmospheric model study of the U.S. High Plains." Monthly Weather Review 131: $556-564$.

Anderson, B. T., J. O. Roads, S. C. Chen, and H. M. H. Juang. 2000. "Regional simulation of the low-level monsoon winds over the Gulf of California and southwestern United States." Journal of Geophysical Research-Atmospheres 105(D14): 17955-17969.

Arnfeld, A. J. 2003. "Two decades of urban climate research: A review of turbulence, exchanges of energy and water, and the urban heat island." International Journal of Climatology 23: 1-26.

Barnston, A. G., and P. T. Schickedanz. 1984. "The effect of irrigation on warm season precipitation in the southern Great Plains." Journal of Climate and Applied Meteorology 23(6): 865-888.

Bell, J. L., L. C. Sloan, and M. A. Snyder. 2004. "Regional changes in extreme climatic events: A future climate scenario." Journal of Climate 17: 81-87.

Betts, A. K. 1986. "A New Convective Adjustment Scheme. 1. Observational and Theoretical Basis." Quarterly Journal of the Royal Meteorological Society 112(473): 677-691.

Boucher, O., G. Myhre, and A. Myhre. 2004. "Direct human influence of irrigation on atmospheric water vapor and climate." Climate Dynamics 22: 597-603.

Chen, F., and Dudhia, J. 2001. "Coupling an advanced land surface-hydrology model with the Penn State-NCAR MM5 modeling system. Part I: Modeling implementation and sensitivity." Monthly Weather Review 129: 569-585.

Chen, S. C., J. O. Roads, H. M. H. Juang, and M. Kanamitsu. 1999. Global to regional simulations of California wintertime precipitation." Journal of Geophysical Research-Atmospheres 104(D24): 31517-31532.

Chou, M.-D., and K.-T. Lee. 1996. "Parameterizations for the absorption of solar radiation by water vapor and ozone." Journal of Atmospheric Science 53: 1203-1208.

Chou, M.-D., and M. J. Suarez. 1994. An efficient thermal infrared radiation parameterization for use in General Circulation Models. TM-1994-104606, 3, National Aeronautical and Space Administration.

Christy, J. R., W. B. Norris, K. Redmond, and K. P. Gallo. 2006. “Methodology and Results of Calculating Central California Surface Temperature Trends: Evidence of Human-Induced Climate Change?" Journal of Climate 19(4): 548-563.

DeFries, R. S., C. B. Field, I. Fung, G. J. Collatz, and L. Bounoua. 1999. “Combining satellite data and biogeochemical models to estimate global effects of human-induced land cover change on carbon emissions and primary productivity." Global Biogeochemical Cycles 13(3): 803-815. 
Dickinson, R. E., A. Henderson-Sellers, and P. J. Kennedy. 1993. Biosphere-Atmosphere Transfer Scheme (BATS) Version 1e as Coupled to the NCAR Community Climate Model. NCAR TN-387+STR, NCAR, Boulder, Colorado.

D.W.R. 1986. Crop Water Use in California. DWR Bulletin 113-4, Sacramento, California.

Eliasson, I. and M. K. Svensson. 2003. "Spatial air temperature variations and urban land use - a statistical approach." Meteorological Applications 10: 135-149.

Elvidge, C. D. et al. 2004. "U.S. constructed area approaches the size of Ohio." EOS, Transactions, American Geophysical Union 85(24): 233.

Feddema, J. J. et al. 2005. "The importance of land-cover change in simulating future climates." Science 310: 1674-1678.

Fritsch, J. M., and Chappell, C. F. 1980. Numerical Prediction of Convectively Driven Mesoscale Pressure Systems. 1. Convective Parameterization. Journal of the Atmospheric Sciences 37(8): 1722-1733.

Gibson, J. K. et al. 1997. ERA Description.

Giorgi, F., J. W. Hurrell, M. R. Marinucci, and M. Beniston. 1997. "Elevation dependency of the surface climate change signal: A model study." Journal of Climate 10: 288-296.

Grell, G. A. 1993. "Prognostic Evaluation of Assumptions Used by Cumulus Parameterizations." Monthly Weather Review 121(3): 764-787.

Grimmond, C. S. B. and T. R. Oke. 1999. "Aerodynamic properties of urban areas derived from analysis of surface form." Journal of Applied Meteorology 38: 1262-1292.

Holtslag, A. A. M., and B. A. Boville. 1993. “Local Versus Nonlocal Boundary-Layer Diffusion in a Global Climate Model." Journal of Climate 6(10): 1825-1842.

Holtslag, A. A. M., E. I. F. Debruijn, and H. L. Pan. 1990. "A High-Resolution Air-Mass Transformation Model for Short-Range Weather Forecasting." Monthly Weather Review 118(8): 1561-1575.

Hong, S.-Y., and H. L. Pan. 1996. "Nonlocal boundary layer vertical diffusion in a mediumrange forecast model." Monthly Weather Review 124: 2322-2339.

Houghton, J. T. et al. (editors). 2001. Climate Change 2001: The Scientific Basis. Contribution of Working Group I to the Third Assessment Report of the IPCC. Cambridge University Press, Cambridge, UK and New York, NY. 881 pp.

Jacobson, M. Z. 1999. "Effects of Soil Moisture on Temperatures, Winds, and Pollutant Concentrations in Los Angeles." Journal of Applied Meteorology 38(5): 607-616.

Jacobson, M. Z. 2004. Effects of Anthropogenic Aerosol Particles and their Precursor Gases on California and South Coast Climate. Final Report to the California Energy Commission. CEC500-2005-003.

Janjic, Z. I. 1990. “The step-mountain coordinate: Physical package." Monthly Weather Review 118(1429-1443). 
Janjic, Z. I. 1994. "The step-mountain Eta coordinate model - Further developments of the convection, viscous sublayer, and turbulence closure schemes." Monthly Weather Review 122: 927-945.

Jin, J., and N. L. Miller. 2006. Coupling of an advanced land surface model with MM5 to improve regional snow simulations. In preparation.

Juang, H.-M., and M. Kanamitsu. 1994. "The NMC Nested Regional Spectral Model." Monthly Weather Review 122: 3-26.

Kalnay, E., and M. Cai. 2003. "Impact of urbanization and land-use change on climate." Nature 423: 528-531.

Kanamaru, H., and M. Kanamitsu. 2005. Scale Selective Bias Correction in Downscaling of Global Analysis Using a Regional Model. CEC-500-2005-130. California Energy Commission, Sacramento.

Kanamitsu, M., et al. 2002. NCEP-DOE AMIP-II Reanalysis (R-2). Bulletin of the American Meteorological Society 83(11): 1631-1643.

Kanamitsu, M., H. Kanamaru, Y. Cui, and H. Juang. 2005. Parallel Implementation of the Regional Spectral Atmospheric Model. CEC-500-2005-014. California Energy Commission, Sacramento.

Kiehl, J. T. et al. 1996. Description of the NCAR Community Climate Model (CCM3). NCAR TN-420+STR, CGD, NCAR.

Kim, J., 2001. "A nested modeling study of elevation-dependent climate change signals in California induced by increased atmospheric $\mathrm{CO}_{2}$." Geophysical Research Letters 28(15): 29512954.

Kim, J., T. K. Kim, R. Arritt, and N. L. Miller. 2002. "Impacts of increased atmospheric $\mathrm{CO}_{2}$ on the hydroclimate of the western United States." Journal of Climate 15: 1926-1942.

Lal, R., and Bruce, J.P. 1999. "The potential of world cropland soils to sequester C and mitigate the greenhouse effect." Environmental Science and Policy 2: 177-185.

Leff, B., N. Ramankutty, and J. A. Foley. 2004. "Geographic distribution of major crops across the world." Global Biogeochemical Cycles 18: GB1009, doi:10.1029/2003GB002108.

Leung, L. R. et al. 2004. "Mid-century ensemble regional climate change scenarios for the western United States." Climatic Change 62: 75-113.

Lin, Y.-L., R. D. Farley, and H. D. Orville. 1983. "Bulk parameterization of the snow field in a cloud model." Journal of Climate and Applied Meteorology 22: 1065-1092.

Loveland, T. R. et al. 1995. "Seasonal land-cover regions of the United States." Annals of the Association of American Geographers 85: 339-355.

Loveland, T. R. et al. 2000. "Development of a global land cover characteristics database and IGBP DISCover from 1-km AVHRR data." International Journal of Remote Sensing 21(6/7): 1303-1330. 
Mitchell, T. D., and P. D. Jones. 2005. "An improved method of constructing a database of monthly climate observations and associated high-resolution grids." International Journal of Climatology 25: 693-712.

Mlawer, E. J., S. J. Taubman, P. D. Brown, R. J. Iacono, and S. A. Clough. 1997. "Radiative transfer for inhomogeneous atmospheres: RRTM, a validated correlated-k model for the longwave." Journal of Geophysical Research 102: 16,663-16,682.

Moorthi, S., and Suarez, M. J. 1992. "Relaxed Arakawa-Schubert: A parameterization of moist convection for general circulation models." Monthly Weather Review 120: 978-1002.

Oke, T. R. 1981. "Canyon geometry and the nocturnal urban heat island: Comparison of scale model and field observations." Journal of Climatology 1: 237-254.

Oleson, K. W. et al. 2004. Technical Description of the Community Land Model (CLM). NCAR/TN-461+STR.

Pal, J. S. et al. Submitted. "The ICTP RegCM3 and RegCNET: Regional Climate Modeling for the Developing World." Bulletin of the American Meteorological Society.

Pal, J. S., E. E. Small, and E. A. B. Eltahir. 2000. "Simulation of regional-scale water and energy budgets: Representation of subgrid cloud and precipitation processes within RegCM." Journal of Geophysical Research-Atmospheres 105(D24): 29579-29594.

Pan, H. L., and Mahrt, L. 1987. "Interaction between soil hydrology and boundary-layer development." Boundary-Layer Meteorology 38(1-2): 185-202.

Pauleit, S., and Duhne, F. 2000. "Assessing the environmental performance of land cover types for urban planning." Landscape and Urban Planning 52: 1-20.

Pielke, R. A. S. et al. 2002. "The influence of land-use change and landscape dynamics on the climate system: Relevance to climate-change policy beyond the radiative effect of greenhouse gases." Philosophical Transactions of the Royal Society of London. Series A, Mathematical and Physical Sciences 360: 1705-1719.

Population Reference Bureau. 2004. 2004 World Population Data Sheet.

Ramankutty, N., and Foley, J. A. 1999. "Estimating historical changes in global land cover: Croplands from 1700 to 1992." Global Biogeochemical Cycles 13(4): 997-1027.

Reynolds, R. W., N. A. Rayner, T. M. Smith, D. C. Stokes, and W. Wang. 2002. "An Improved In Situ and Satellite SST Analysis for Climate." Journal of Climate 15(13): 1609-1625.

Rosenfeld, D., and A. Givati. 2005. "Evidence of orographic precipitation suppression by air pollution induced aerosols in the western USA." Journal of Applied Meteorology In press.

Sailor, D. J. 1995. "Simulated urban climate response to modifications in surface albedo and vegetative cover." Journal of Applied Meteorology 34: 1694-1704.

Sala, O. E. et al. 2000. "Global biodiversity scenarios for the year 2100." Science 287: 1770-1774.

Schar, C., D. Luthi, U. Beyerle, and E. Heise. 1999. "The Soil-Precipitation Feedback: A Process Study with a Regional Climate Model." Journal of Climate 12(3): 722-741. 
Segal, M., Z. Pan, R. W. Turner, and E. S.Takle. 1998. "On the potential impact of irrigated areas in North America on summer rainfall caused by large-scale systems." Journal of Applied Meteorology 37: 325-331.

Snyder, M. A., J. L. Bell, L. C. Sloan, P. B. Duffy, and B. Govindasamy. 2002. "Climate responses to a doubling of atmospheric carbon dioxide for a climatically vulnerable region." Geophysical Research Letters 29(11): 10.1029/2001GL014431.

Snyder, M. A., and L. C. Sloan. 2005. "Transient future climate over the Western U.S. using a regional climate model." Earth Interactions 9: Paper 11.

Tao, W. K., J. Simpson, and M. McCumber. 1989. "An ice-water saturation adjustment." Monthly Weather Review 117: 231-235.

USDA. 2004. 2002 Census of Agriculture. USDA National Agricultural Statistics Service.

USDA Forest Service. 2001. 1997 Resources Planning Act (RPA) Assessment. USDA Forest Service, Washington, D.C.

Watson, R. T. et al. (editors). 2000. Land Use, Land-Use Change, and Forestry. Cambridge: Cambridge University Press. 377 pp.

Zeng, X., M. Zhao, and R. E. Dickinson. 1998. "Intercomparison of Bulk Aerodynamic Algorithms for the Computation of Sea Surface Fluxes Using TOGA COARE and TAO Data." Journal of Climate 11(10): 2628-2644. 